\title{
Demirci Küpeler Köyü Camii Duvar Resimleri
}

\author{
Murals of The Mosque of Demirci Kupeler Village
}

\section{Cengiz Gürbıyık* $₫$}

\section{Öz}

XVIII. yüzyıldan itibaren Osmanlı İmparatorluğu'nun Batı ile artan ilişkileri sonucu yeni bir sanat ortamı doğmuş ve süsleme sanatında duvar resmi olarak anılan yeni bir tür ortaya çıkmıştır. Öncelikle İstanbul'da saray ve çevresinde karşımıza çıkan bu süsleme anlayışı, zamanla tüm Anadolu'ya yayılmıştır. İstanbul'un aksine Anadolu'da özellikle camilerin yoğun biçimde alçı ve kalemişi süslemelerle bezendiği gözlenmektedir. Kalemişi ustaları ya da usta grupları tarafından yapılan bu süslemelerde, batı etkili motiflerin yanı sıra çeşitli dinsel ve sembolik tasvirlere de yer verilmiştir. Köy köy gezerek sanatlarını icra eden bu gezici ustaların pek çoğu icra ettikleri sanat eserlerine imza atmaktan imtina ettiklerinden genellikle isimleri bilinmemektedir. Ancak az da olsa bazı usta isimlerine rastlamak mümkündür. İncelemiş olduğumuz Demirci Küpeler Köyü Camii'nde ise hem yapı ustasının hem kalemişi süslemeleri yapan müzehhibin hem de hattatın isimlerinin verilmiş olması bu açıdan dikkat çekicidir. Cami, dıştan basit bir görünüşe sahip olmasına rağmen iç mekânı zengin kalemişleri ile süslenmiştir. Süslemelerle birlikte dini içerikli hat yazılar da kullanılmıştır. Çalışmamızda yapı plan ve süsleme özellikleri bakımından ayrıntılı biçimde ele alınmaktadır.

\section{Anahtar Kelimeler}

Küpeler Köyü, Cami, Duvar resmi, Bezeme, Kalemişi

\begin{abstract}
As a result of the increasing relations of the Ottoman Empire with the West as of the 18th century, a new art environment was born, and a new type, called mural, emerged in the decoration art. This decoration approach, which primarily became popular in the palace and its environment in Istanbul, spread all over Anatolia in the course of time. Contrary to Istanbul, it is observed that, especially mosques were adorned with plaster and engravings in Anatolia. In these decorations, made by painted decoration masters or master groups, western influenced motifs as well as various religious and symbolic depictions were also included. Since many of these masters performing their art by traveling from village to village refrained from putting their signatures on their works of art, their names are generally unknown. However, it is possible to come across some masters' names, though not many. In the Demirci Küpeler Village Mosque, which we studied, it is noteworthy that the names of the master builder, as well as the illuminator and calligrapher who performed the engravings, were given. Although the mosque has a plain exterior appearance, its interior is adorned with a rich painted decoration. Religious calligraphy scripts were also used along with decorations. In our study, the building is discussed in detail, with respect to its plan and characteristics.
\end{abstract}

\section{Keywords}

Küpeler Village, Mosque, Murals, Ornament, Painted decoration

* Sorumlu Yazar: Cengiz Gürbıyık (Dr. Öğr. Üyesi), Manisa Celal Bayar Üniversitesi, Fen Edebiyat Fakültesi, Sanat Tarihi Bölümü, Manisa, Türkiye. E-posta: cengizgurbiyik@gmail.com ORCID: 0000-0002-9325-9841

Atıf: Gurbiyik, Cengiz. “Demirci Küpeler Köyü Camii Duvar Resimleri.” Art-Sanat, 13 (2020): 143-167.

https://doi.org/10.26650/artsanat.2020.13.0006 


\section{Extended Summary}

Styles such as baroque and rococo in Europe were effective in architecture and architectural decoration in the Ottoman geography after the middle the 18th century. The murals that first emerged and developed in the capital city, Istanbul, spread all over Anatolia, especially with the influence of the notable and gentry people, and different styles and concepts were developed in various regions of the empire. Contrary to Istanbul, it is observed that, especially mosques in Anatolia were predominantly adorned with plaster and painted decorations. In these decorations, made by painted decorations masters or master groups, western style motifs, as well as various religious and symbolic depictions, were included. Since many of these travelling masters, who performed their art by moving village to village, refrained from signing the works they created, their names are generally unknown. However, it is possible to come across the names of some masters, albeit rarely.

Located in the village of Küpeler, after which it was named, in the Demirci district of Manisa, the old mosque offers interesting data with both the calligraphy plates encircling the prayer hall and the inscriptions that also involve the names of masters. Located on the upper part of the village on a fairly sloping terrain from west to east and south, the mosque consists of a longitudinal rectangular prayer hall and a narthex to the north. The prayer hall, with a longitudinal rectangular plan, is covered with a flat wooden ceiling. There is the women's prayer area, which is carried by four wooden pillars to the north of the prayer hall.

Intensive painted decorations and wooden decorations can be observed in the ceiling of the narthex, the women's prayer area, ambo and minbar of the mosque. The plain wooden ceiling of the narthex was divided transversely with lath, and vivified by painting the interiors with different colours. The ceiling fringe is encircled with a strip, made of painted decorations, from three directions. The strip, featuring handmade successive floral bundles, ends with a blue outline at the bottom.

The decoration program on the northern wall of the prayer hall is rather interesting. There is no certain pattern in the decorations. The calligraphy plates and motifs on the surface demonstrate a disorderly spread. There are calligraphies over the entrance, giving information on the construction date, restoration date and builders of the structure. These calligraphies are written within three circular frames with different sizes, and the space above these frames. The frames, that are not perfectly even, are outlined in navy blue. Flower bundles, coming out of vase, are depicted over the window apertures on the northern facet of the prayer hall. These bundles, with green leaves, have blue, clove-like flowers. A pomegranate tree with fruits is depicted on the area between the entrance and the window aperture to the east. One of the most remarkable decorations on the facet is the depiction of a halberd and a bowl hanged next to it at the bottom of the east side of the facet. This decoration which bears cru- 
cial importance, in terms of the dervish lodge iconography, is unfortunately not in a good state. The ship icon located at the upper side of the same area has more naive characteristics, while resembling other examples in Anatolia. A stanza, that is called devriyye, draws attention at the bottom of this ship figure which was able to stay in good state. The ship, which is on a blue strip symbolizing the sea, is made with a black contour, and the hull with the shape of a strip is coloured in green. Two wheels draw attention on the hull of the steam ship with three masts. Certain details, such as the red flags on the masts and the dark fumes coming out of the chimney, give a more realistic mood to the depiction. Two much smaller sized sailboats are depicted in the front and back of the ship.

Painted decorations of various sizes and forms can be found on the prayer hall walls of the structure. The painted decorations continue with a total of eleven medallions on the eastern, western and southern walls of the prayer hall and the rosette on the south wall. The medallions are framed with blue and orange, and black calligraphies are placed on the white background in them. The space between the medallions, on the other hand, is filled with motifs of flowers coming out of vases of different types. There is a tasseled sword figure which gives the impression of being hung on the wall on the western wall right over the minbar. The body of the brown-hilted sword is of indigo color. The tree figures on the southern wall of the prayer hall are very interesting. A total of six tree motifs depicting olive, orange, cypress and date trees, four of which are in the upper section and two in the lower section, are placed on the southern part of the prayer hall.

According to the inscriptions over the entrance, the building was built in 779/137778, and then repaired in 1307/1889-90 by Hatip Ismail Efendi. The inscriptions also indicate that the construction master was a man named Kiymikci Mustafa, that the calligraphy writings in the mosque were made by calligrapher Mehmet Emin and the decorations were made by illuminator Mehmet, from the Sofiler Quarter of Demircili. The mosque, whose first construction was completed in the 14th century, was probably demolished to a large extent, and today's mosque was built in the 19th century.

The structure shows similarities especially with several mosques in the Aegean and Mediterranean regions, in terms of inscriptions and decorations. However, the decorations are more simple and naive than those in other mosques. Another remarkable issue is that the names of both the master of the building, the illuminator and the calligrapher are given in the inscriptions of the mosque. We do not have detailed information yet about these masters, who adorned even a modest mosque in a small mountain village in the Inner Western Anatolia with such intense decorations and calligraphies, and who we think were affiliated to the dervish lounges operating in the region. However, further studies and field research to be conducted on this subject matter will allow us to reach new and interesting data. 


\section{Giriş}

Manisa’nın Demirci İlçesi’nde, adını aldığı Küpeler Köyü’nde bulunan eski cami', gerek harimi çevreleyen hat levhaları gerek kalem işi süslemeleri ve gerekse usta isimlerini de içeren kitabeleriyle ilgi çekici veriler sunmaktadır. Yapı daha önce bir envanter çalışması kapsamında kısaca ele alınmış ${ }^{2}$ ancak bugüne kadar hakkında ayrıntılı bir değerlendirme yapılmamıştır.

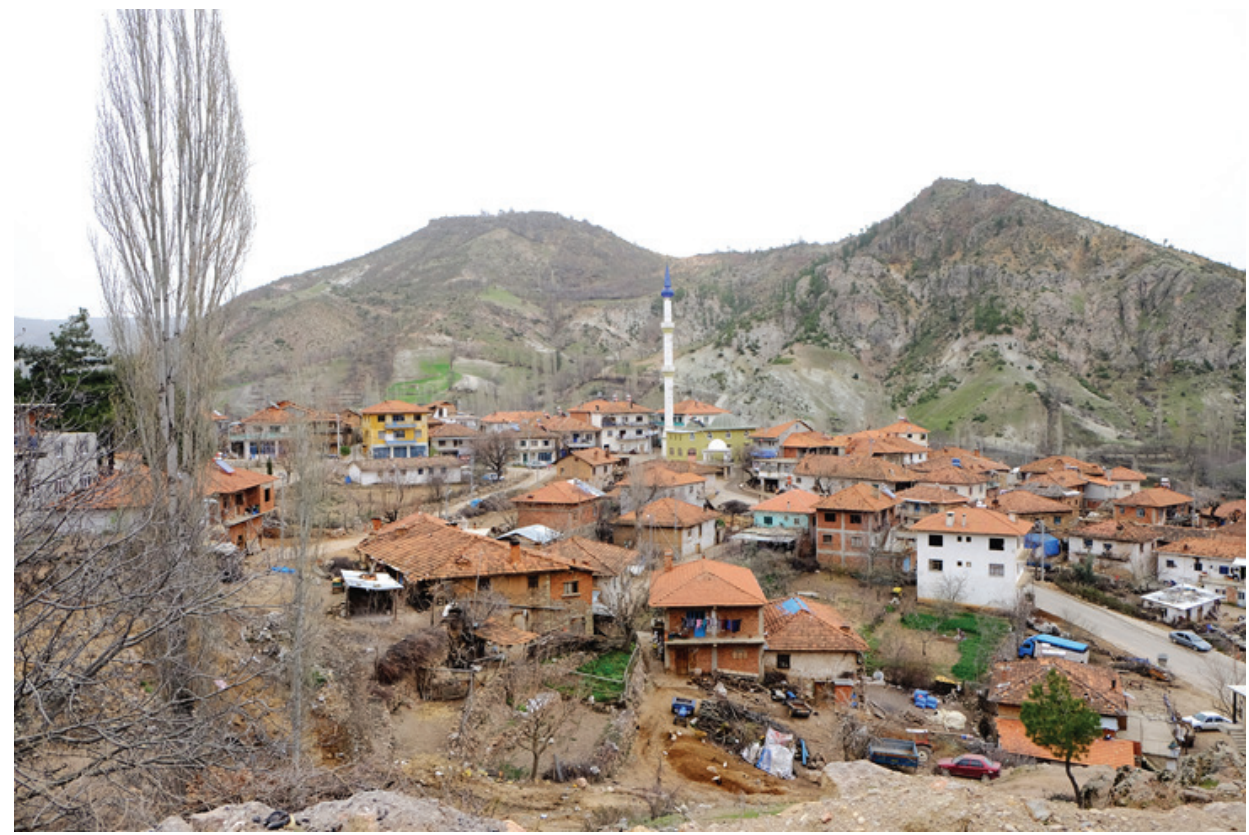

G. 1. Demirci Küpeler Köyü (C. Gürbıyık, 22.03.2018)

Küpeler Köyü, Manisa İli Demirci İlçesi’nin yaklaşık 30 km güneydoğusunda yer almaktadır (G. 1). Köye ilişkin en erken tarihli verilere XVI. yüzyıl tahrir kayıtlarında rastlanmak mümkündür. 1531 tahririnde Küpiler olarak anılan köyde, 1 imam bulunduğu ve nüfusun 135 kişi olduğu belirtilmekte ayrıca bir caminin varlığından bahsedilmektedir. ${ }^{3}$ Hurûfât defterlerine göre köyün XVIII. yüzyılda artık Küpüler olarak anılmaya başladığı ve 1761-1814 yılları arasında camide 5 hatibin görevlendirilmiş olduğu anlaşılmaktadır. ${ }^{4}$ XIX. yüzyılın ikinci yarısında Karataş Nahiyesine bağlı olan ve yine Küpüler olarak anılan köyün nüfusu 68 hane ve yaklaşık 300 kişiden oluşmaktadır. $^{5}$

1 Köye yakın bir geçmişte yeni bir cami inşa edilmiştir.

2 Fatih Müderrisoğlu, "Köpüler Köyü Eski Camii," Türk Kültür Varlıkları Envanteri Manisa İlçeleri, ed. Hakkı Acun, (Ankara: Türk Tarih Kurumu Yayınları 2013), 37-46.

3 Kadir Adamaz, "XVI. yüzyılda Demirci Kazası”" (Doktora tezi, Celal Bayar Üniversitesi, 2012), $108,195$.

4 Ertan Gökmen, "Hurûfât Defterlerine Göre Demirci Kazası ve Köylerinde Cami ve Mescitler (1690-1830)," Celal Bayar Üniversitesi Sosyal Bilimler Dergisi 3/2 (2005), 52.

5 Ertan Gökmen, Tanzimat'tan II. Meşrutiyet'e Demirci Kazası (İzmir: Demirci Belediyesi Kültür Yayınları 2007), 112-113. 
Küpeler Köyü, 228 Ada 3 parselde bulunan tescilli cami, köyün üst kısmında, Azmahalle Mevkii olarak adlandırılan bölgede yer almaktadır (G. 2). Günümüzde restorasyon çalışmaları devam eden caminin kuzeyindeki küçük meydancıkta bulunan anıtsal çınar ve kuzeybatısında 1957 yılında inşa edilmiş yuvarlak kemerli duvar çeşmesi, geleneksel dokuyu tamamlamaktadır.

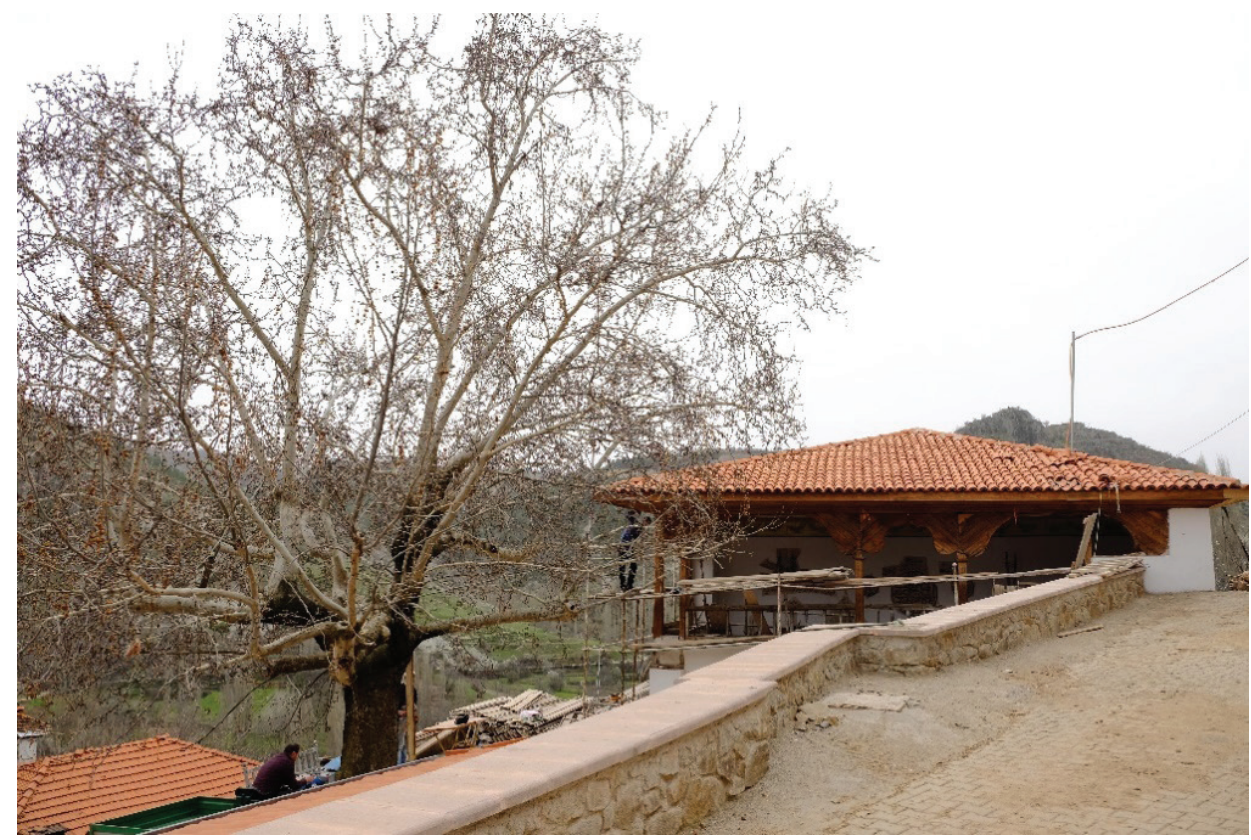

G. 2. Küpeler Köyü Camii. Kuzeyden genel görünüm (C. Gürbıyık, 22.03.2018)

Batıdan doğuya ve güneye doğru oldukça eğimli bir arazi üzerine konumlanmış olan yapı, uzunlamasına dikdörtgen şekilli bir harim ve kuzeyindeki son cemaat yerinden oluşmaktadır. Eğimden dolayı cepheler arasında ciddi kot farkı bulunmaktadır. Yapı kırma çatıyla örtülü ve kiremit kaplıdır. Cephelerde dikdörtgen şekilli ikişer pencere açıkı̆̆gna yer verilmiştir. Doğu cephesinin üst kısmında kadınlar mahfilini aydınlatan bir başka pencere açıklığı daha yer almaktadır.

Bir ana kaya üzerine inşa edilen yapının tüm cepheleri sıvalıdır. Ancak onarım çalışmaları sırasında sıvaların kaldırılan bölümlerinden inşa malzemesi hakkında yorum yapabilmek mümkündür. Yapıda inşa malzemesi olarak alt kısımda kaba yonu taş ve moloz taş, üst kısımda ise kerpiç kullanıldığı gözlenmektedir. Yapının son cemaat yerine bakan kuzey duvarı ise ahşap karkas bir düzenlemeye sahiptir ve diğer cephelere oranla çok daha ince tutulmuştur. 

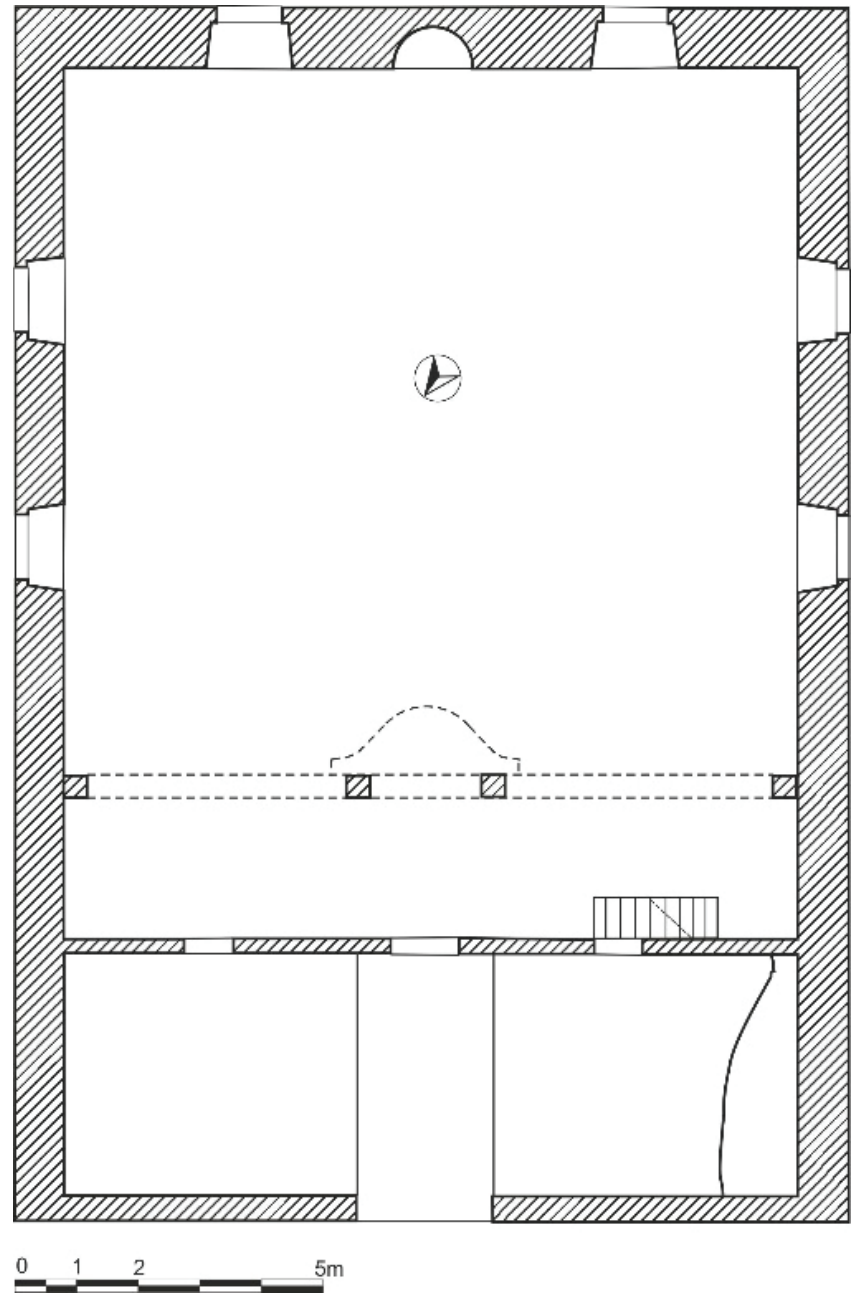

G. 3. Küpeler Köyü Camii. Plan (Cengiz Gürbıyı)

Harimin kuzeyinde bir son cemaat yeri bulunmaktadır. Düz ahşap tavanlı son cemaat yerinin batı cephesi tamamen kapalıdır. Doğu ve kuzey cepheleri ise yaklaşık $1.70 \mathrm{~m}$ yüksekliğinde bir duvarla çevrilidir. Son cemaat yeri, duvarların üzerinde birbirlerine kemerlerle bağlanan kare kesitli ahşap desteklerle kuzeyde üç, doğuda ise bir kemer gözüyle dışa açılmaktadır. Harim giriş cephesinde ortada bir giriş açıklı̆̆ı ve iki yanda dikdörtgen şekilli birer pencere açıklığına yer verilmiştir. Giriş açıklığının üzerinde yapının inşa tarihi, onarım tarihi ve inşa ettiren kişiler hakkında bilgileri içeren hat yazılar ve duvar yüzeyinde dağınık biçimde yerleştirilmiş̧ çeşitli motifler göze çarpmaktadır (G. 4) 


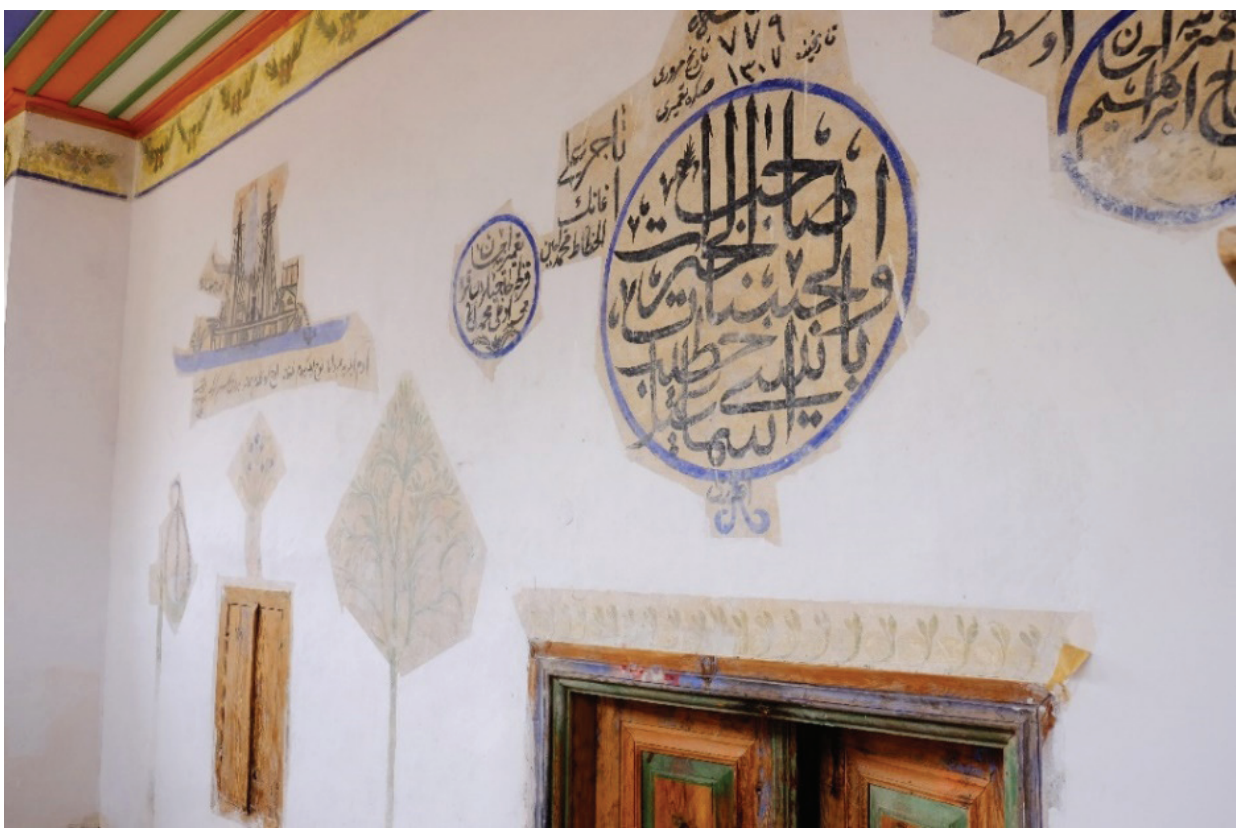

G. 4. Harim kuzey cephesi (C. Gürbıyık, 22.03.2018)

Uzunlamasına dikdörtgen planlı harim, düz ahşap tavanla örtülüdür (G. 5). Harimin kuzey kesiminde kare kesitli dört ahşap destekle taşınan bir kadınlar mahfili mevcuttur (G. 6).

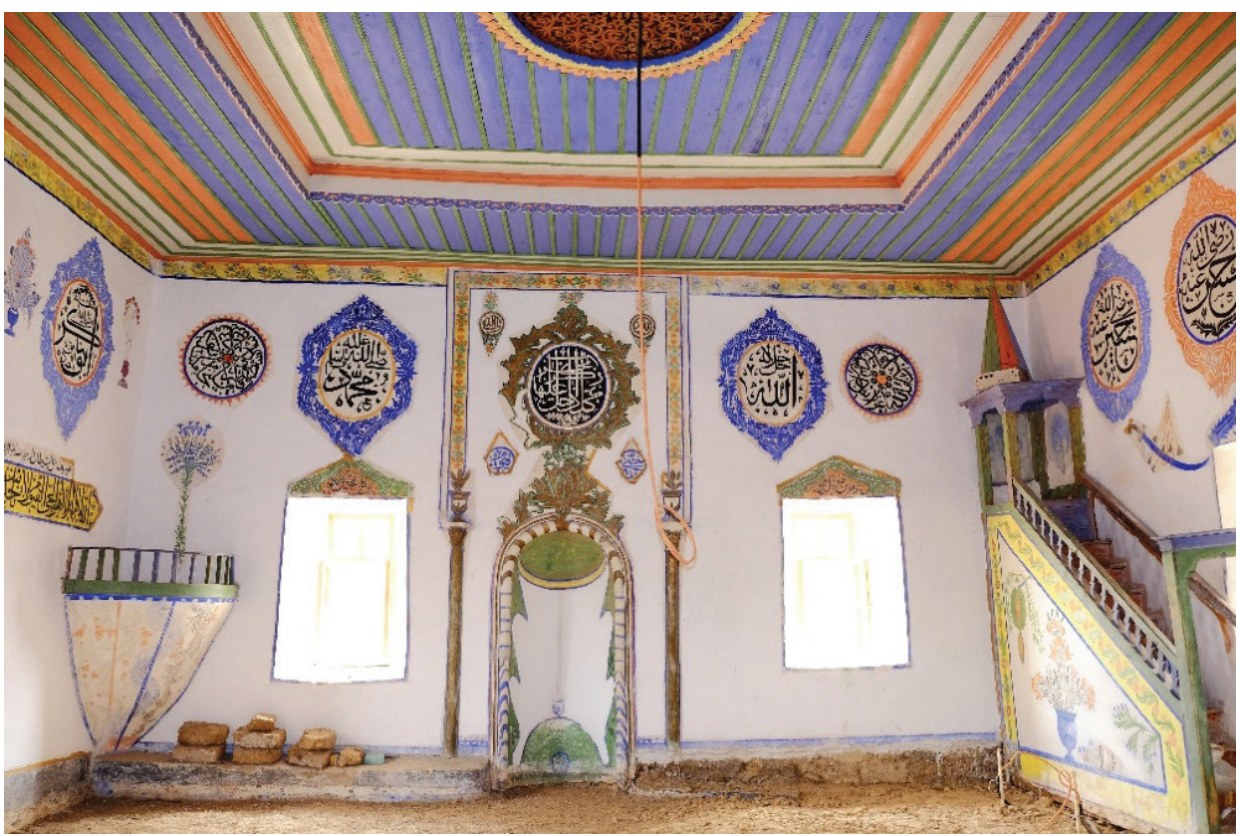

G. 5. Harim güney duvarı (C. Gürbıyık, 22.03.2018). 
Yapının yarım daire profilli mihrap nişi, çeyrek küre şekilli bir kavsaraya sahiptir. Niş iki yandan sütuncelere oturan bir şeritle çevrelenmektedir. Özellikle niş içerisinde bulunan süslemelerin bir dönem kötü bir biçimde elden geçirildiği anlaşılmaktadır (G. 5). Yapının ahşap minberi de süslemeleriyle dikkat çekmektedir. Minberin aynalık kısmı alçıyla sıvanmış ve bu alan tümüyle kalemişi süslemelerle donatılmıştır. Mihrabın doğusunda yer alan vaaz kürsüsü de minber gibi alçıyla sıvanmış ve alçı üzeri kalemişi tekniğiyle süslenmiştir.

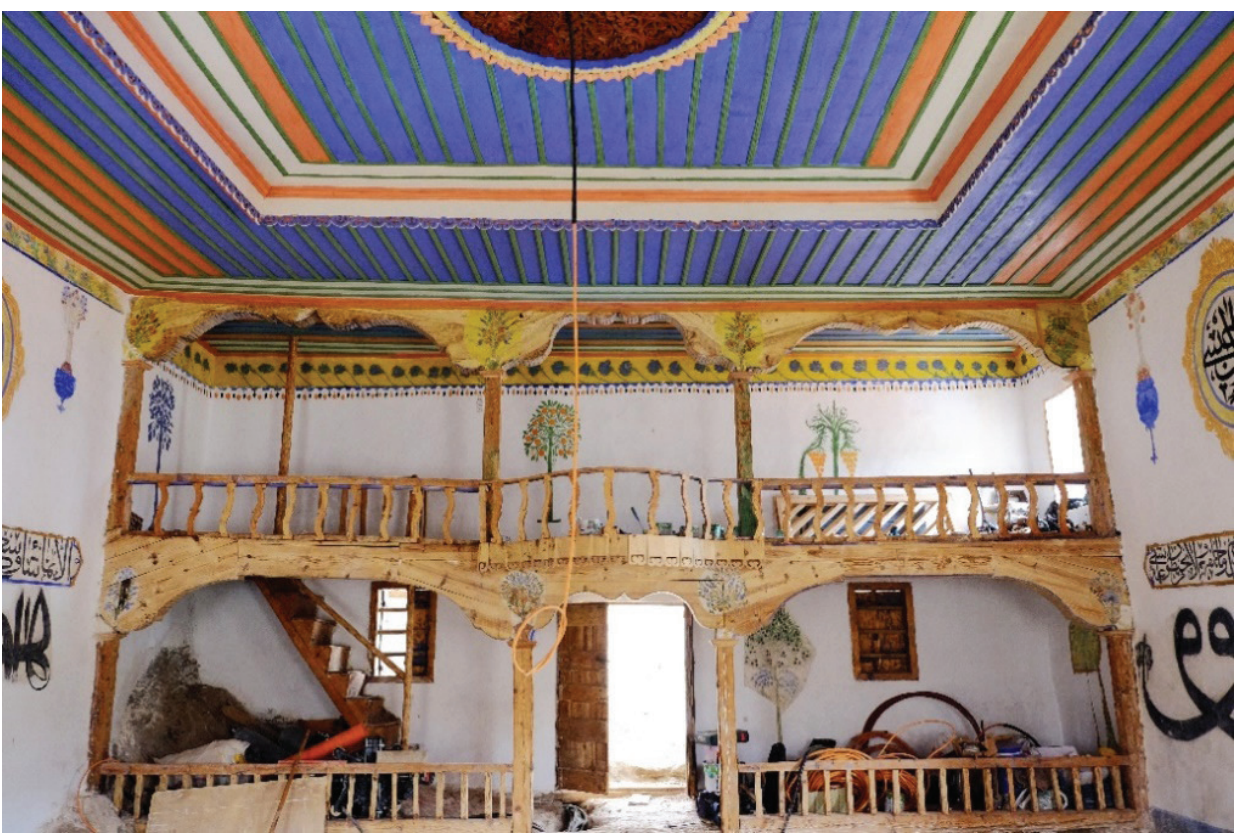

G. 6. Harimin kuzey duvarı ve kadınlar mahfili (C. Gürbıyık, 22.03.2018)

\section{Süslemeler}

Caminin son cemaat yeri tavanı, harim kuzey cephesi, harim iç duvarları ve tavanı, kadınlar mahfili, vaaz kürsüsü ve minberde yoğun bir kalemişi ve ahşap süslemeye yer verildiği gözlenmektedir (G. 5, G. 6, G. 7, G. 8)

Yapıdaki kalemişi bezemeler ilk olarak son cemaat yerinde ve harim kuzey duvarında karşımıza çıkmaktadır. Son cemaat yerinin düz ahşap tavanı çıtalarla enine bölünüp içleri farklı renklerde boyanarak hareket kazandırılmıştır. Tavan saçağı ise üç yönden kalemişi ile oluşturulmuş bir şeritle çevrelenmektedir. İçerisinde elle yapılmış birbirini takip eden bitkisel çiçek demetlerinin yer aldığı şerit, altta mavi bir konturla sonlanmaktadır. Sarı renkli bir tabana sahip olan şeridin içerisinde yeşil yapraklar ve bunların arasında turuncu meyvelere yer verilmiştir. 


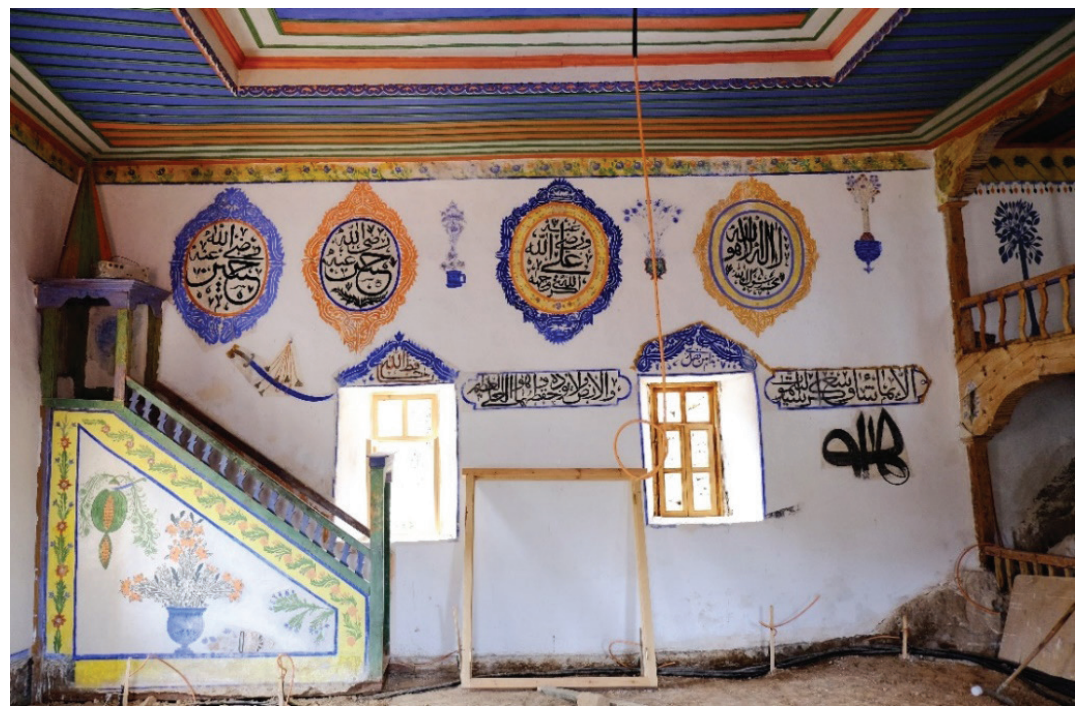

G. 7. Harim batı duvarı ve minber (C. Gürbıyık, 22.03.2018)

Harim kuzey duvarında yer alan süsleme programı oldukça ilgi çekicidir. Süslemelerde belli bir düzen söz konusu değildir. Yüzeydeki hat levhalar ve motifler dağınık bir yayılım göstermektedir (G. 4). Giriş açıklığının üzerinde yapının inşa tarihi, onarım tarihi ve inşa ettiren kişiler hakkında bilgileri içeren hat yazılar yer almaktadır. $\mathrm{Bu}$ yazılar farklı büyüklükteki üç dairesel çerçeve içerisine ve onların üzerindeki alanlara yazılmıştır. Çok düzgün olmayan çerçeveler lacivert renkle oluşturulmuştur. Yazıların üzeri zamanın ve doğanın tahribatıyla kısmen solmakla birlikte iyi durumdadır. Ancak üzerlerinde geçmişte yapılan müdahalelerden çeşitli boya lekeleri kalmıştır.

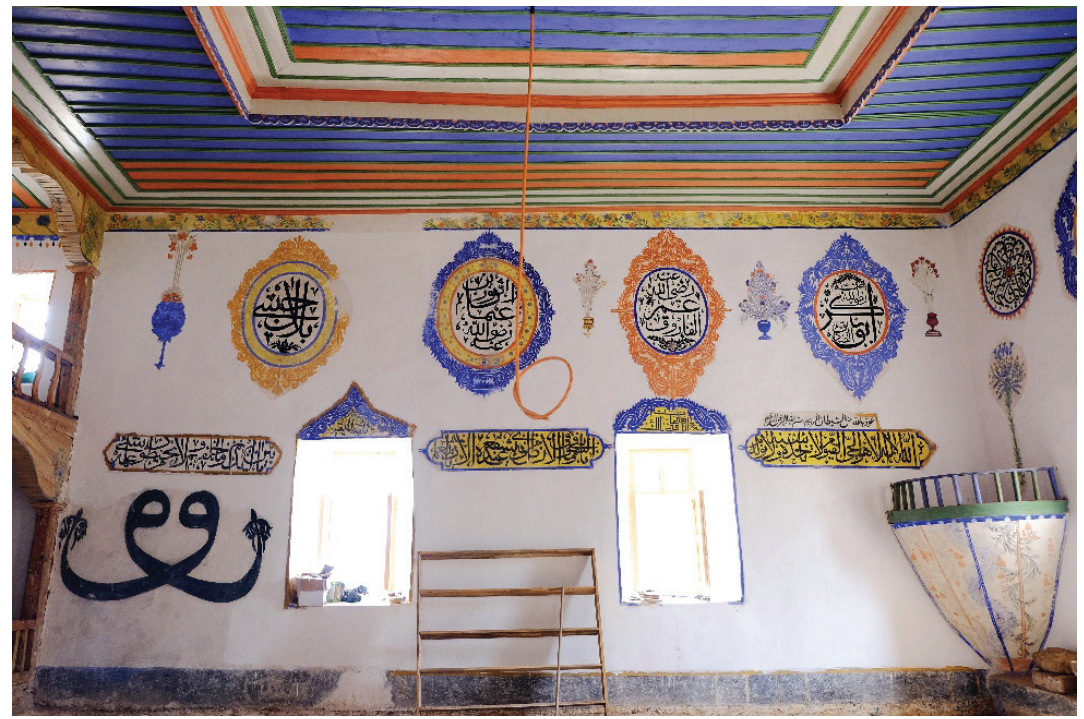

G.8. Harim doğu duvarı (C. Gürbıyık, 22.03.2018) 
Harim kuzey cephesindeki pencere açıklıklarının üzerinde, vazodan çıkan çiçek demetlerine yer verilmiştir. Yeşil yapraklı bu demetler, mavi renkli karanfil benzeri çiçeklere sahiptir. Giriş açıklığıyla doğudaki pencere açıklığı arasındaysa üzerinde meyveleriyle birlikte bir nar ağacı betimlenmiştir.

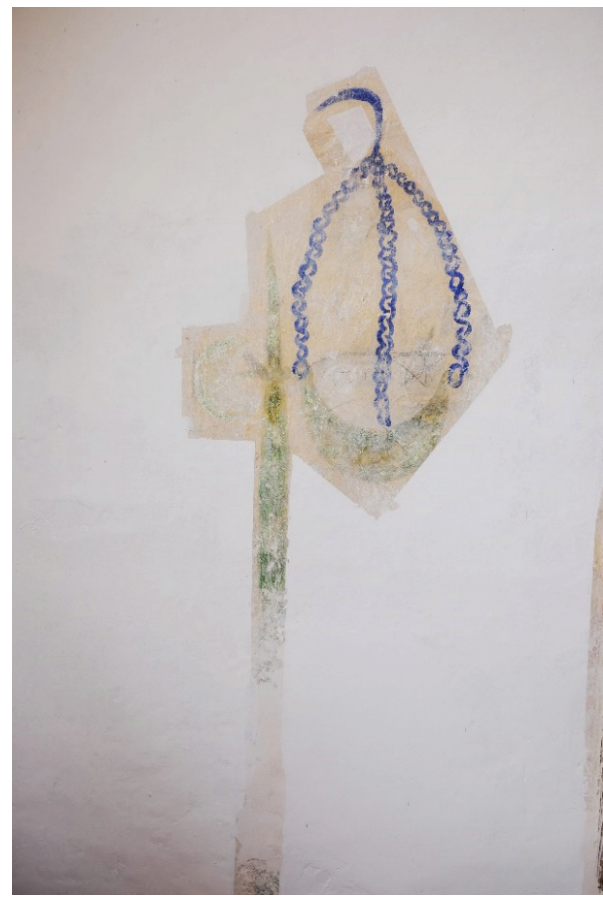

G. 9. Harim kuzey cephesindeki keşkül ve teber tasviri (C. Gürbıyık, 22.03.2018)

Cephedeki en dikkat çekici süslemelerden biri, cephenin doğusunda alt bölümde yer alan bir teber ve yanına asılı keşkül tasviridir (G. 9). Tekke ikonografisi bakımından oldukça anlam taşıyan bu süslemeler ne yazık ki iyi durumda değildir. Süsleme zamanla silinmiş, keşkülün zincir kısmıysa sonradan üzerinden geçilerek tekrar boyanmıştır.

Aynı alanda üst bölümde yer alan gemi tasviriyse Anadolu'daki diğer örneklere benzemekle birlikte daha naif özellikler taşımaktadır (G. 10). Sağlam durumda kalabilmiş gemi motifinin alt kısmında "devriyye" olarak adlandırılan bir dörtlük dikkati çekmektedir. Denizi simgeleyen mavi bir şerit üzerinde bulunan gemi, siyah konturla oluşturulmuş ve şerit şeklindeki gövdesi yeşil renkle boyanmıştır. Üç direkli ve buhar11 geminin gövdesinde iki çark mevcuttur. Direklerin üzerindeki kırmızı flamalar ve bacadan çıkan koyu renkli buhar gibi ayrıntılar tasvire daha gerçekçi bir hava katmıştır. Geminin ön ve arkasında çok daha küçük boyutlu birer yelkenliye yer verilmiştir. Yelkenlilerden biri gemiye zincirle bağlanmış durumdadır. Suya atılmış şekilde tasvir edilen çapanın oranıysa gemiye kıyasla oldukça büyüktür. 


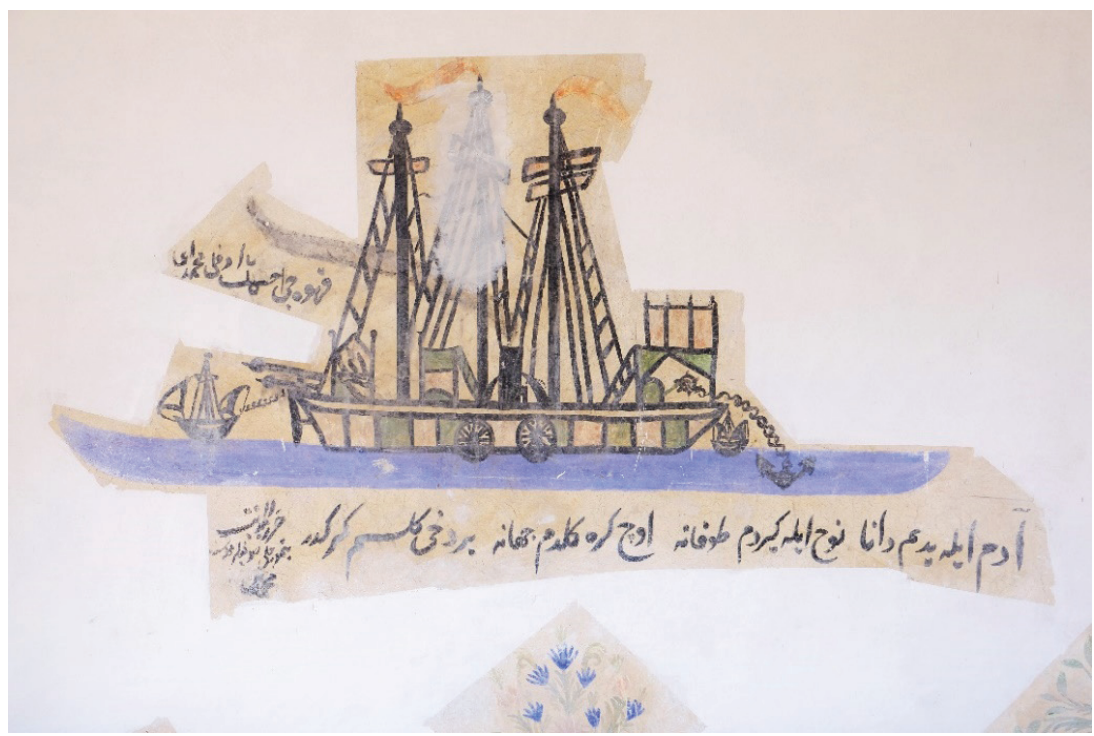

G. 10. Harim kuzey cephesindeki buharlı gemi motifi (C. Gürbıyık, 22.03.2018)

Son cemaat yeri her türlü dış etkilere açık olduğundan zaman içerisinde cephedeki sıva üzerindeki renk değişmiş ve kirlenmiştir. Günümüzde cephe yüzeyinin bütününe bakıldığında mevcut süslemelerin zemin renklerinin kreme yakın kirli bir renge sahip olduğu, cephenin diğer yüzeylerinin ise çok daha açık beyaza boyandığı anlaşılmaktadır. Bu yüzden cephe bir bütün olarak algılanmamakta, süslemeler birer yama gibi görünmektedir (G. 4).

Harimin boyuna uzanan ahşap çıtalarla hareketlendirilen iki kademeli tavanının ortasında, incelikli bir ahşap işçiliğine sahip dairesel formda bir göbek bulunmaktadır. $\mathrm{S}$ ve $\mathrm{C}$ kıvrımlı ahşap süslemelerden oluşan göbeğin çevresini zikzak şeklinde iki sıra ahşap çıta çevrelemektedir.

Yapının harim duvarlarında da çeşitli boyut ve formlarda kalemişi süslemelere rastlanmaktadır. Kalemişi süslemeler harimin doğu, batı ve güney duvarlarında yer alan toplam on bir madalyon ve güney duvarında yer alan rozetlerle devam etmektedir (G. 5, G. 6, G. 7, G. 8). Kuzey duvarındaysa çeşitli ağaç tasvirlerine yer verilmiştir. Madalyonlar kartuşların üst kısmından başlayıp tavana kadar uzanmaktadır.

Harimin saçak kısmı bir bordürle dört yönden çevrelenmektedir. Kuzey cephede kadınlar mahfilinin olduğu bölümdeki bordürün diğerlerine oranla biraz daha geniş tutulduğu ve içerisindeki bitkisel motifin de farklı olduğu gözlenmektedir. Sarı bir zemin üzerinde yeşil yapraklı mavi ve kırmızı çiçek demetleriyle dolgulandırılmış olan bordürün özellikle doğu cephede kısmen zarar gördüğ̈u ve bazı bölümlerin tamamen silindiği anlaşılmaktadır. 
Doğu ve batı duvarlarında bulunan dikdörtgen şekilli toplam beş kartuşun içerisine, doğu cephesinin güneyinden başlayarak Ayet-el Kürsi yazılmıştır. Mavi renkle sınırlandırılan kartuşların bir kısmında sarı zemin rengi karşımıza çıkmaktadır. Doğu, batı ve güney duvarında yer alan toplam on bir madalyonda ise batı duvarından başlayarak sırasıyla, Kelime-i Tevhid, Ali, Hasan, Hüseyin, Allah, Muhammed, Ebubekir, Ömer, Osman ve Bilal Habeşi'nin isimleri yazmaktadır (G. 5, G. 7, G. 8.). Mihrabın hemen üzerindeki kartuşta ise genelde tüm cami mihraplarında gördüğümüz $A l-i$ Imran suresinin 37. ayetinden bir bölüm yer almaktadır. Bunun yanı sıra pencere açıklıklarının üzerinde stilize bitkisel motiflerle üçgen birer tepelik oluşturulmuş ve bunların içerisi Hâzâ min fadli Rabbî, Yâ hâfiz'ullah, Innâ fetahnâ leke fethan mubînâ El-mukadder lâ yugayyer ve min külli feccin 'amîk gibi çeşitli ayetlerden bölümler ve dini içerikli yazılarla doldurulmuştur. Hatlar ağırlıklı olarak celî sülüs ile yazılmıştır. Ancak pencere açıklıklarının üzerinde kûfî ve ta'lîk gibi yazı çeşitlerine de yer verilmiştir.

Madalyonlar mavi ve turuncu renk ile çerçevelenmiş, içlerine ise beyaz zemin üzerine siyah hat yazılar yerleştirilmiştir. Madalyonlar arasında kalan boş alanlarsa farklı tipteki vazolardan çıkan çiçek motifleriyle hareketlendirilmiştir.

Güney duvarının doğu ve batı köşelerindeyse dairesel şekilli birer rozet bulunmaktadır. Güneş kursu şeklindeki rozetler, mavi konturla çevrelenmiştir. Doğudaki rozetin içerisinde dört büyük meleğin, batıdakinde ise yedi uyurların isimleri yazılmıştır (G. 5). Pencere açıklıklarının üzerinde yine kalemişi ile oluşturulmuş birer tepelik mevcuttur. Tepeliklerin içerisinde çeşitli ayetlere yer verilmiştir.

Harimin doğu ve batı duvarının güneyinde büyük boyutlu hatlara da rastlanmaktadır. Doğu duvarında iç içe geçmiş iki "vav" harfi, batı duvarında ise büyük bir "Hu" yazısı göze çarpmaktadır. Ancak bu bölümdeki vav harfinin alt kısmı zamanla tahrip olmuştur (G.7, G. 8). Batı duvarında minberin hemen üzerinde, duvara asılı izlenimi veren püsküllü bir kılıç motifi dikkati çekmektedir. Kahverengi saplı kılıcın gövdesi çivit mavisi rengindedir (G. 7, G. 13).

Yapının yarım daire profilli mihrap nişi çeyrek küre şekilli bir kavsarayla örtülüdür (G. 5). Niş iki yandan sütuncelere oturan bir şeritle çevrelenmektedir. Bu şerit yine sarı zemin üzerine yeşil ve turuncu renklerdeki bitki kompozisyonlarıyla doldurulmuş ve mavi konturla sınırlandırılmıştır. Nişin üzerinde kalemişi ile oluşturulmuş bir tepelik ve onun üzerinde içinde bir hat bulunan bir göbek dikkati çekmektedir. Nişin içerisinde iki yana çekilmiş bir perde motifi ve ortadan sarkan kandil motifine yer verilmiştir. Özellikle niş içerisinde bulunan süslemelerin bir dönem kötü bir biçimde elden geçirildiği anlaşılmaktadır. 


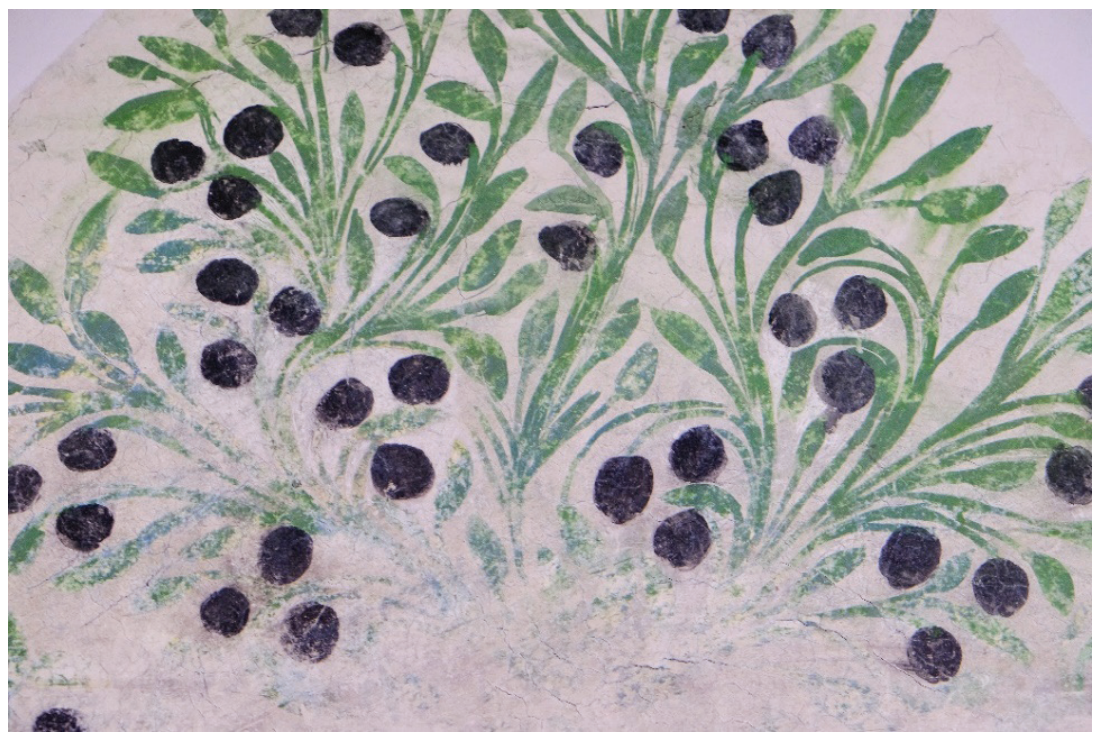

G. 11. Harim güney duvarındaki zeytin ağacından ayrıntı (C. Gürbıyık, 22.03.2018).

Harimin güney duvarında bulunan ağaç motifleri oldukça ilgi çekicidir. Harimin güneyinde üst bölümde dört, alt bölümdeyse iki olmak üzere toplam altı ağaç motifine yer verilmiştir. Girişin hemen doğusunda alt kesimde yeşil-kahverengi gövdesi, koyu yeşil yaprakları ve siyah meyveleriyle bir zeytin ağacı tasvir edilmiştir (G. 11). Güneybatı köşedeyse gövdesi kısmen tahrip olmuş ancak koyu yeşil geniş yaprakları ve turuncu meyveleriyle portakal olduğu anlaşılan bir başka ağaç bulunmaktadır.

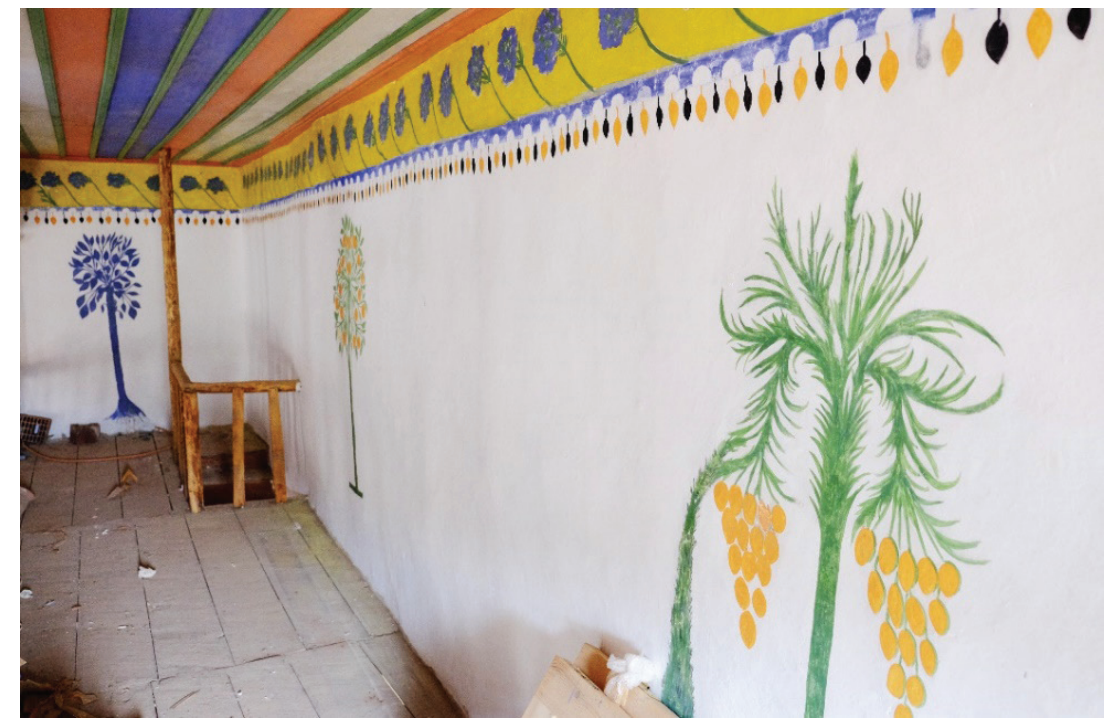

G. 12. Harim güney duvarındaki hurma, selvi ve portakal ağacı (C. Gürbıyık, 22.03.2018) 
Güney duvarında kadınlar mahfilinin bulunduğu üst bölümde de farklı ağaçlar karşımıza çıkmaktadır. Ancak üst bölümdeki bu ağaçlar daha yakın bir geçmişte tekrar elden geçirildiklerinden kısmen özgünlüklerini yitirmiş durumdadır (G. 12). Duvarın doğusunda olgunlaşmış turuncu meyveleri ve yeşil gövdesiyle bir hurma ağacı ve hemen yanında başını hafif eğmiş bir selvi tasvir edilmişken, duvarın batısına doğru koyu yeşil gövdesi, daha açık yeşil renkli yaprakları ve turuncu meyveleriyle bir portakal ağacı işlenmiştir. Harim batı duvarının güneyinde ise mavi gövdesi ve mavi yapraklarıyla meyvesi bulunmayan ve türü tam olarak anlaşılamayan bir başka ağaç daha mevcuttur (G. 12).

Harim duvarlarında da son cemaat yerinde olduğu gibi süslemelerin zeminiyle cephenin diğer zemini arasında büyük bir ton farkı bulunmaktadır.

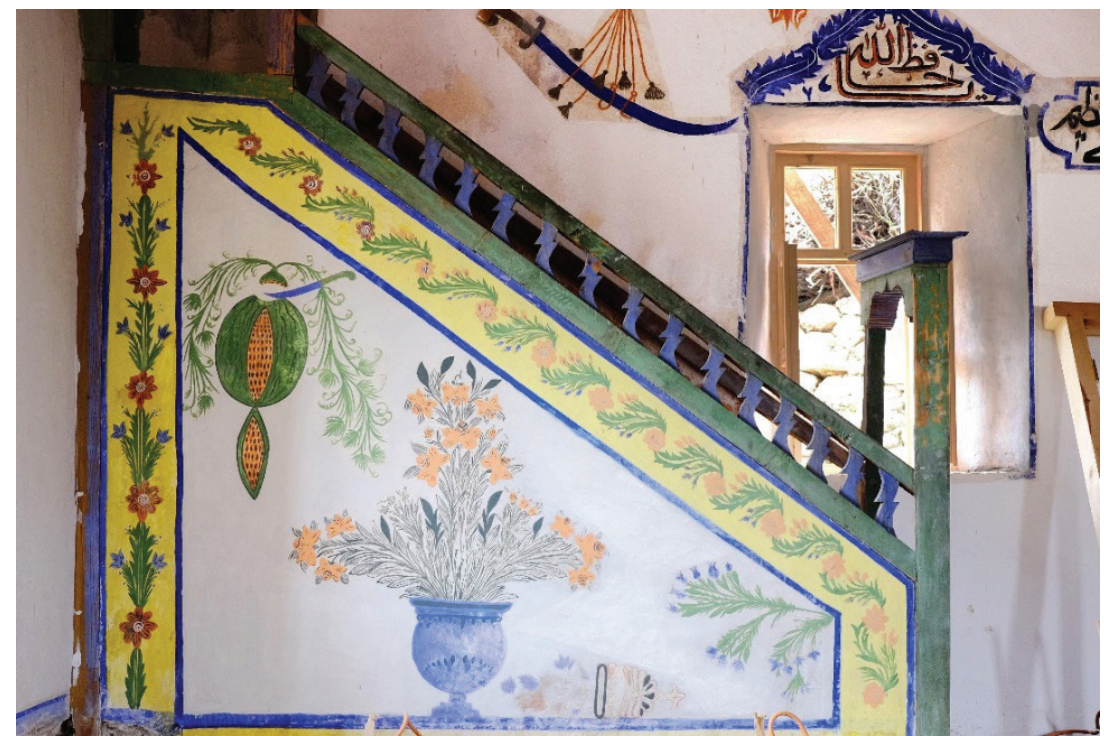

G. 13. Minber aynalığındaki kalemişi süslemeler (C. Gürbıyık, 22.03.2018)

Yapıda sıva dışında kadınlar mahfilinde olduğu gibi ahşap üzerine yapılmış kalemişleri de bulunmaktadır. Kadınlar mahfilinin harime bakan yüzünde ahşap desteklerin hemen üzerinde altta ve üstte dörder süsleme örneği karşımıza çıkmaktadır. Vazodan çıkan çeşitli çiçek demetlerinden oluşan bu süslemelerin her biri diğerinden farklıdır ve büyük ölçüde sağlam durumdadırlar. Süslemelerin taban renkleri dikkate alındığında ahşabın aşı boyayla yapılmış zemin renginin, alt seviyede beyaz, üst katta ise sarı olduğu anlaşılmaktadır. Mahfili destekleyen ayaklarda ise yeşil rengin kullanıldığı gözlenmektedir.

Yapının ahşap minberinin aynalık kısmı alçıyla sıvanmış ve bu alan tümüyle kalemişi süslemelerle donatılmıştır (G. 13). Minber aynalığ saçaktaki şeritlere benzer şekilde -mavi konturla sınırlandırılmış sarı zeminli, içleri bitkisel bezemelerden olu- 
şan- bir şeritle çevrelenmektedir. Şeridin alt kısmında herhangi bitkisel bir bezeme yoktur. Sol ve üst kısımda yer alan bitkisel bezemelerse farklılık göstermektedir. Aynalığın içinde ise beyaz bir zemin tercih edilmiş, ortada büyük bir vazodan çıkan çiçek demetleri, onun hemen yanında devrilmiş bir vazo ve diğer yanda benzer süslemeli yapılarda da sıklıkla karşılaşılan dilimlenmiş bir karpuz ve bıçak motifi yer almaktadır. Karpuzun bir süsleme ögesi olarak kıvrım dallar şeklinde işlenen sapları, oldukça zarif biçimde verilmiştir. Minberde bulunan kalemişi süslemeler büyük ölçüde sağlam durumdadır. Sadece aynalığın alt kısmındaki şerit kısmen rengini kaybetmiştir.

Vaaz kürsüsü de minber gibi alçıyla sıvanmış ve alçı üzeri kalemişi tekniğiyle süslenmiştir. Kürsünün alt bölümü mavi ve turuncu şeritli konturla bölünmüş ve içlerine bu konturları çevreleyen sarmaşık şeklinde stilize bitkisel motifler yerleştirilmiştir.

\section{Tarihlendirme}

Giriş açıklığının üzerinde bulunan hat yazılardan yapının inşa tarihi, onarım tarihi ve inşa ettiren kişiler hakkında ilgi çekici bilgilere ulaşmak mümkündür (G. 14) ${ }^{6}$. Bu yazılar farklı büyüklükteki üç dairesel çerçeve içerisine ve onların arasındaki alanlara yazılmıştır. Çok düzgün olmayan çerçeveler, çivit mavisi rengindeki konturlarla oluşturulmuştur. Yazılar yerleştirtilirken herhangi bir simetri kaygısı gözetilmemiştir.

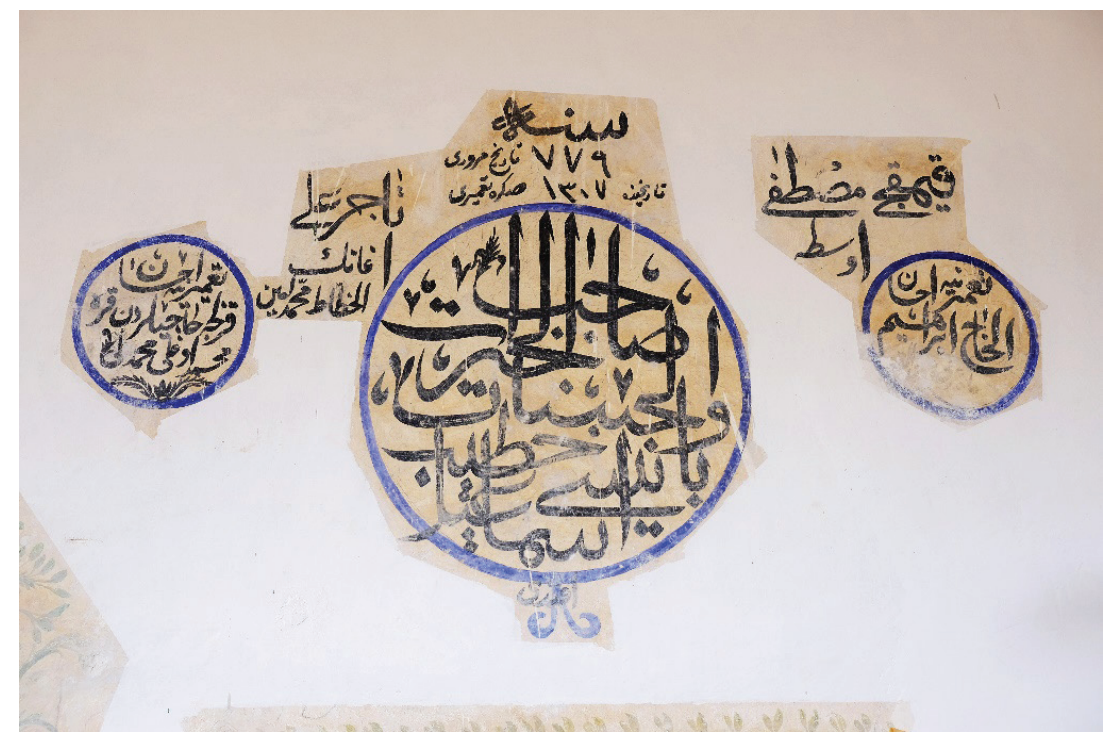

G. 14. Harim giriş açıklığı üzerindeki kitabe levhaları (C. Gürbıyık, 22.03.2018)

Ortadaki diğerlerine oranla daha büyük daire içerisindeki kitabe ile hemen üzerindeki inşa kitabesinin metni ve okunuşu şöyledir:

6 Kitabelerin okunuşundaki yardımları için Prof. Dr. Ertan Gökmen ve Dr. Öğr. Üyesi İlker M. Çağlar’a teşekkürlerimi sunarım. 


\section{سنـة \\ تاريخى مرورى VV9

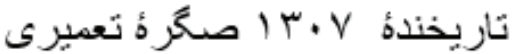 \\ صاحب الخبرات و الحسنات بانيسي خطيب اسماعيل افندى \\ Sene \\ 779 [1377-78] Tarih-i mürûri \\ Tarihinde 1307 [1889-90] sonra tamiri ${ }^{7}$ \\ Sahib'ül-hayrat ve'l- hasenat banisi Hatib İsmail Efendi}

Batıdaki madalyonun içerisinde

$$
\begin{aligned}
& \text { Tamirine Ihsan } \\
& \text { El hac Ibrahim }
\end{aligned}
$$

$\mathrm{Bu}$ madalyonun hemen üzerinde

$$
\begin{aligned}
& \text { (اوسيمقى مصطفى } \text { Kiymıkci Mustafa } \\
& \text { Usta }
\end{aligned}
$$

Doğudaki madalyonun içerisinde

$$
\begin{aligned}
& \text { Tamirine İhsan } \\
& \text { Karacahacllardan Kara } \\
& \text { Mehmed Oğlu Mehmed }
\end{aligned}
$$

Doğudaki madalyon ile ortadaki büyük madalyon arasında ise

$$
\begin{aligned}
& \text { تاجر على } \text { Tacir Ali } \\
& \text { A أغانكa'nın } \\
& \text { El hattat Mehmed Emin }
\end{aligned}
$$

yazmaktadır. Harim giriş açıklığı üzerindeki bu ilgi çekici bilgilerin yanında doğudaki pencere açıklığının üzerinde de bazı yazılar dikkati çekmektedir. Bu alanda üç direkli, buharlı ve yandan çarklı büyük bir gemi tasvir edilmiş ve geminin çevresinde bazı hat yazılara yer verilmiştir (G. 10). Geminin hemen doğusunda, yelken direğinin önündeki yazının metni ve okunuşu şöyledir:

7 Kitabenin bu satırının "Sonra Tamiri 1307 tarihinde" şeklinde okunması daha doğrudur. Ancak özgün metin bu şekilde yazılmıştır. 


$$
\text { قهو فُجى احمد او غلو محمد اعا }
$$

Kahveci Ahmed oğlu Mehmed A $\breve{g} a$

tek bir sıra hâlinde geminin hemen altındaysa

$$
\begin{aligned}
& \text { ادم ايله يدم دانا نوح ايله كيردم طو فانه او تج كره كلدم جهانه بر دخى كلسم كركدر } \\
& \text { المذهب تيمرجيلى صوفيلر محله سندهن محمد }
\end{aligned}
$$

Adem ile yedim dana Nuh ile girdim tufana üç kere geldim cihana bir daha gelsem gerekdir.

El-müzehhib Demircili Sofiler Mahallesi'nden Mehmed

yazmaktadir.

Kitabelerden de anlaşılacağı üzere yapı ilk olarak 779/1377-78 yılında inşa edilmiş, ardından 1307/1889-90 yılında Hatip İsmail Efendi tarafından onartılmıştır. Bu onarım sırasında Hacı İbrahim ve Karacahacılardan Kara Mehmet oğlu Mehmet adlı kişiler de ihsanda bulunmuşlardır. Kitabelerden ayrıca yapı ustasının Kıymıkçı Mustafa adlı biri olduğu, camideki hat yazıların el-hattat Mehmet Emin tarafından, süslemelerinse Demircili Sofiler Mahallesi'nden el-müzehhib Mehmet tarafından yapıldığ anlaşılmaktadır. Kitabelerde ayrıca Kahveci Ahmet oğlu Mehmet Ağa ve Tacir Ali Ağa adlı kişilerin de isimleri geçmektedir.

Yapının ilk inşasına dair herhangi bir kitabe levhası ya da belge bulunmamaktadır. Ancak erken tarihli pek çok belgede Küpeler Köyü ve camisine ait bilgilere ulaşmak mümkündür. ${ }^{8}$ Demirci ve çevresinin XIV. yüzyılın başlarında Türklerin eline geçtiği ve bölgenin Saruhanoğullarının egemenliği altında bulunduğu bilinmektedir. ${ }^{9}$ Olasılıkla cami ilk olarak Saruhanoğulları döneminde inşa edilmiştir. XIX. yüzyıldaki onarımı sırasında var olduğunu düşündüğümüz özgün kitabeyse günümüze ulaşamamıştır. Ancak günümüzdeki yapı, plan şekli, süsleme özellikleri ve inşa malzemesi dikkate alındığında onarım tarihi olan XIX. yüzyılın tipik özelliklerini taşımaktadır. Daha erken dönemde inşa edilen cami, olasılıkla büyük ölçekte yıkılmış ve yerine günümüzdeki cami inşa edilmiştir.

\section{Değerlendirme ve Karşılaştırma}

Demirci Küpeler Köyü Camii mimari açıdan anıtsal bir yapı olmamakla birlikte gerek harimi çevreleyen hat levhaları gerek kalem işi süslemeleri ve gerekse usta isimlerini de içeren kitabeleriyle ilgi çekici veriler sunmaktadır.

Mimari açıdan değerlendirildiğinde doğrudan doğruya beden duvarına oturan düz ahşap tavanı ve uzunlamasına dikdörtgen planıyla özellikle XVII. ve XIX. yüzyıllar

8 Gökmen, "Hurûfât Defterlerine Göre Demirci Kazası ve Köylerinde Cami ve Mescitler (1690-1830)," 52; Adamaz, "XVI. yüzyılda Demirci Kazası," 195.

9 Feridun Emecen, "Saruhanoğulları," Türkiye Diyanet Vakfi İslam Ansiklopedisi, c. 36 (İstanbul: Türkiye Diyanet Vakfı Yayınları, 2009), 170-171. 
arasında Anadolu'da inşa edilen çok sayıda cami ile benzerlikler göstermektedir. Düşük maliyeti ve basit kuruluşlarından dolayı çevredeki pek çok yerleşimde bu plan tipindeki camilere rastlamak mümkündür. Foça Hafız Süleyman Mescidi (XVIII. yüzy1l) ${ }^{10}$, Karaburun Tepeboz Köyü Camii (XVIII. yüzy1l) ${ }^{11}$ ve Uşak Akarca Köyü Camii (XIX. yüzyıl) ${ }^{12}$ bölgedeki düz ahşap tavanlı camilere örnek olarak verilebilir. Harim giriş açıklığı üzerindeki kitabelerden birinde Kıymıkçı Mustafa Usta adı geçmektedir (G. 14). Muhtemelen bu kişi, yapının son şeklini aldığı XIX. onarımında inşaatın başındaki usta olmalıdır. Kıymıkçı Mustafa Usta'nın adına en azından şu ana kadar başka bir yapıda rastlanmamıştır.

Yapıda süslemelerle birlikte dini içerikli hat yazılar da kullanılmıştır. Harimin doğu, batı ve güney duvarları, dikdörtgen şekilli kartuşlar ve dairesel madalyonların içerisinde Allah, Muhammed, Hasan, Hüseyin ve dört halife ile yedi uyurların isimlerinin bulunduğu hat levhalarla bezenmiştir (G. 5, G. 7, G. 8). Hat sanatı, mimaride bir süsleme unsuru olarak her dönem sevilerek kullanılmıştır. Harim duvarlarının yoğun bir şekilde hat yazılarla süslendiği çok sayıda cami örneği bulunmaktadır. Denizli Baklan Boğaziçi Kasabası Eski Camii (1774-75) ${ }^{13}$, Yuntdağ 1 Yenice Mahallesi Camii (1901-02) ${ }^{14}$, Yuntdağ Karakılınçlı Mahallesi Camii (1907-08), Ödemiş Lübbey Köyü Camii (XX. yüzyıl ilk yarıs1) ${ }^{15}$, Bursa Keles Dedeler Köyü Camii (XX. yüzyı1) ${ }^{16}$ ve Kırşehir Mucur Emine Hanım Camii (XX. yüzyıl başı) ${ }^{17}$ hat yazıların yoğun olarak kullanıldığı benzer örnekler olarak verilebilir. Harim giriş açıklığı üzerindeki kitabe kartuşlarından bir diğerinde Tacir Ali Ăga'nın el hattat Mehmet Emin şeklinde bir yazıya rastlanmaktadır (G. 14). Tacir Ali Ağa'nın oğlu olduğunu düşünebileceğimiz Mehmet Emin, yapıdaki hat yazıları yazan kişidir. Hattat Mehmet Emin'in yerel bir hat sanatçısı olup olmadığı ya da bölgedeki farklı yapılarda çalışıp çalışmadığı hakkında herhangi bir bilgiye ulaşılamamıştır.

Yapının en ilgi çekici unsuru olan kalemişi süslemeler, harim duvarları ve son cemaat yerinde karşımıza çıkmaktadır. Duvarlar ince beyaz bir alçı tabakasıyla sıvanmış, sıva üzerine lacivert ve turuncu çerçevelerle panolar oluşturulmuş ve içleri

10 Şakir Çakmak, "Foça'daki Türk Eserleri," Geçmişten Günümüze Foça Uluslararası Sempozyumu (İzmir: Foça Belediyesi Yayınları,1996), 52-53.

11 Cengiz Gürbıyık, Karaburun Yarımadası'nda Türk Mimarisi (İstanbul: Arkeoloji ve Sanat Yayınları 2009), 142-148.

12 Elif Gürsoy, "Uşak İli Sivaslı İlçesi Akarca Köyü Camisi," Elektronik Sosyal Bilimler Dergisi 62 (Temmuz 2017) 1007, erişim 8 Mayıs 2019. https://doi.org/10.17755/esosder.329109.

13 Şakir Çakmak, "Boğaziçi Kasabası Eski Cami (Baklan/Denizli)," Dokuzuncu Milletlerarası Türk Sanatları Kongresi: 23-27 Eylül 1991, (Ankara: Kültür Bakanlı̆̆g Yayınları, 1995), 1:533.

14 Halil İbrahim Eryılmaz, "Yuntdağı Yenice Mahallesi Camii Yazıları," MCBÜ Sosyal Bilimler Dergisi 16-3 (2018), 545-580

15 Emin Başaranbilek, Lübbey Kışlağı ve Lübbey Camisi (İstanbul: Mas Matbaacılık, 2015), 71-77.

16 Hicabi Gülgen, "Bursa Keles İlçesi Dedeler Köyü Camii ve Süslemeleri," Uludağ Üniversitesi İlahiyat Fakültesi Dergisi 21/1 (2012), 63-86.

17 Şerife Tali, "Kırşehir/Mucur'daki Hüseyin Ağa Camii ile Emine Hanım Camii’nin Kalemişleri," Uluslararası Sosyal Araştırmalar Dergisi Prof. Dr. Hamza Gündoğdu Armağanı 6/25 (2013), 526, fot. 35. 
geometrik, sembolik, natürel ve stilize edilmiş bitkisel kompozisyonlarla bezenmiştir. Mevcut süslemeler Batılılaşma dönemi duvar resim sanatının karakteristik özelliklerini göstermekle birlikte yerel bir sanatçı tarafından meydana getirilmiş naif resimlerdir.

XVIII. yüzyıl ortalarından itibaren Avrupa'daki barok, rokoko, ampir gibi üsluplar Osmanlı coğrafyasında mimari ve mimari süslemede etkili olmuştur. İlk olarak başkent İstanbul'da ortaya çıkan ve gelişim gösteren duvar resimleri, özellikle ayan ve eşraftan kişilerin de etkisiyle tüm Anadolu'ya yayılmış ve böylece imparatorluğun çeşitli bölgelerinde farklı üslup ve anlayışlar meydana gelmiştir. İstanbul'un aksine Anadolu'da özellikle camilerin yoğun biçimde alçı ve kalemişi süslemelerle bezendiği gözlenmektedir. Kalemişi ustaları ya da usta grupları tarafından yapılan bu süslemelerde çeşitli manzaralar, mimari tasvirler, natürmortlar, C-S kıvrımlı kartuşlar ve vazodan çıkan çiçek demetleri gibi batı etkili motiflerin yanı sıra çeşitli dinsel ve sembolik tasvirlere de yer verilmiştir ${ }^{18}$.

Yapının son cemaat yeri ve hariminde sıkça karşımıza çıkan bitkisel bezemeler ve vazodan çıkan çiçek demetleri bu dönemin duvar resim sanatında sevilerek ele alınan süsleme unsurlarının başında gelmektedir. Soma Hızır Bey Camii (1791-92) ${ }^{19}$, Denizli Acıpayam Yazır Köyü Camii (1802-03) ${ }^{20}$, Soma Damgacı Camii (1872) ${ }^{21}$, Muğla Kurşunlu Camii (XIX. yüzyıl sonu)22 ve Eski Mordoğan Köyü Ayşe Kadın Camisi (süslemeler XVIII. yüzyılın başı) ${ }^{23}$ gibi yapılarda yoğun bitkisel süslemelere rastlamak mümkündür.

Küçük boyutlu bitkisel süslemelerin dışında harimin özellikle güneyinde çok sayıda ağaçla minber aynalığı üzerinde bıçakla kesilerek bir dilimi ayrılmış karpuz motifine yer verilmiştir (G. 11, G. 12, G. 13). Nar, hurma, selvi, portakal ve zeytin harim duvarındaki tanımlayabildiğimiz ağaçlar arasındadır. Türkler tarafından farkl1 semboller ifade eden nar, incir, üzüm, hurma, zeytin, dut, kavun ve karpuz gibi meyveler ve ağaçlar çeşitli el sanatlarında sevilerek kullanılan unsurlardan bazılarıdır. Özellikle incir, zeytin, üzüm, hurma, selvi ve nar gibi meyveler ve ağaçlar dini sembolizmle de yakın ilişkilidir. Anadolu kültürünün hemen her alanında karşımıza çıkan simgelerden biri olan nar bolluk ve bereketi; İslamiyet’te cennete özgü ağaçlar arasında sayılan hurma, sonsuz yasamı; zeytin ağacı da barışı ve arınmayı sembolize

18 Bu konuda ayrıntılı bilgi için bkz. Rüçhan Arık, Batılılaşma Dönemi Anadolu Tasvir Sanatı, (Ankara: Türkiye İş Bankası Kültür Yayınları, 1976); Günsel Renda, Batılılaşma Dönemi Türk Resim Sanatı 1750-1850 (Ankara: Hacettepe Üniversitesi Yayınları, 1977); Pelin Şahin Tekinalp, "Batılılaşma Dönemi Duvar Resmi," Türkler Ansiklopedisi, c. 15, (Ankara: Yeni Türkiye Yayınları 2002), 440-448; Oktay Hatipoğlu, “XIX. yüzyı1 Osmanlı Camilerinde Kalem işi Tezyinatı” (Doktora Tezi, Atatürk Üniversitesi, 2007).

19 Rüçhan Arık, Batılılaşma Dönemi Türk Mimarisi Örneklerinden Anadolu'da Üç Ahşap Cami (Ankara: A.Ü. DTCF Yayınları, 1973), 45, res. 15-16.

20 Arık, Batılılaşma Dönemi Anadolu Tasvir Sanatı, 44.

21 İnci Kuyulu, “Geç Dönem Anadolu Tasvir Sanatından Yeni Bir Örnek: Soma Damgacı Camii,” ArkeolojiSanat Tarihi Dergisi IV (1988), lev XXII, res.11.

22 Şakir Çakmak, Muğla Cami ve Mescitleri (Muğla: Muğla Belediyesi Kültür Yayınları 2013), 37.

23 Gürbıyı, Karaburun Yarımadası'nda Türk Mimarisi, 28. 
etmektedir. ${ }^{24}$ Selvi ağaciysa cennete yükselen boyu ve hafif eğilmiş başıyla genellikle hayat ağacı olarak tasvir edilir. Tepesi kesilmiş ve üzerine bıçak saplanmış ya da bir dilimi çıkarılmış karpuz da duvar resminde sevilerek kullanılan motiflerden biridir.

Bu çeşit süsleme unsurları Kula Emre Köyü Camii (1547-48)25, Koçarlı Cincin Köyü Cihanoğlu Camii (XVIII. yüzyı1) ${ }^{26}$, Çivril Savranşah Camii (XVIII. yüzy11)27, Denizli Baklan Boğaziçi Kasabası Eski Camii (1774-75)28 Ödemiş Bademli Kılcızade Mehmet Ağa Camii (1811) ${ }^{29}$, Kırkağaç Çiftehanlar Camii (XIX. yüzyıl) ${ }^{30}$ Çivril-Bulgular Köyü Camii (XIX. yüzyı1) ${ }^{31}$ ve Afyonkarahisar Dazkırı İdris Köyü Camii (XX. yüzyıl başları) ${ }^{32}$ gibi çok sayıda yapıda karşımıza çıkmaktadır.

Süsleme repertuarında çok sık karşılaşmadığımız portakal ağacı, Küpeler Köyü Camii'nde iki ayrı yerde kullanılmıştır. Bu ağaçların benzerini Giresun Tekke Köyü Hacı Abdullah Halife Camii33'nde (XIX. yüzyıl) görmek mümkündür. Ancak bu camideki ağaçlar daha ziyade limonu andırmaktadır.

Yapının son cemaat yerinde harim kuzey duvarı üzerinde oldukça büyük boyutlu, üç direkli, yandan çarklı ve buharlı bir gemi motifi yer almaktadır (G. 10). Sanayi devriminin sembolü olan buharlı gemiler, XIX. yüzyıl başlarından itibaren kullanılmaya başlamıştır. Yelkenli gemilerin çarklı ve buharlı gemilere dönüşüm aşamaları Anadolu duvar resimlerinde sıkça karşılaştığımız bir unsurdur. ${ }^{34}$ İzmir Bayraklı Yahya Hayati Paşa Köşkü (XIX. yüzyıl) üst kat sofa tavanında ${ }^{35}$, Demirci Ağa Camii (183435) harim tavan eteğinde ${ }^{36}$, Amasya Merzifon Kara Mustafa Paşa Camii şadırvanında

24 R. Eser Gültekin, "Türklerde Bereket Sembolü Olarak Kullanılan Meyve Motifleri ve Mimaride Değerlendirilmesi," Turkish Studies 3/5(2008), 12-13, erişim 11 Mayıs 2019. http://dx.doi.org/10.7827/TurkishStudies.408

25 Rüstem Bozer, "Kula-Emre Köyünde Resimli Bir Cami,” Türkiyemiz 53 (1987), 15-22.

26 Tuğçe Yurtsal, “Aydın ve Denizli Camilerinde Duvar Resimleri” (Yüksek Lisans Tezi, Gazi Üniversitesi, 2009), 243.

27 Yurtsal, “Aydın ve Denizli Camilerinde Duvar Resimleri,” fot. 305,311,312, 316.

28 Çakmak, "Boğaziçi Kasabası Eski Cami (Baklan/Denizli)," 531.

29 İnci Kuyulu, “Bademli Kılcızade Mehmet Ağa Camii,” Vakıflar Dergisi 24 (1994), 146- 158.

30 İnci Kuyulu, "Kırkağaç Çiftehanlar Camii," Arkeoloji-Sanat Tarihi Dergisi V (1990), 114.

31 Kadir Pektaş ve Hediye Gelen Altındirek, "Çivril Bulgurlar Köyü Camii Üzerine," Eumeneia Şeyhlü-Işıkll, ed. Bilal Söğüt, (İstanbul: Ege Yayınları 2011), 326.

32 Şeyda Algaç, “Afyonkarahisar Dazkır-İdris Köyü Camii ve Kalemişi Bezemeleri,” Van Yüzüncü Yll Üniversitesi Sosyal Bilimler Enstitüsü Dergisi 2 (2017), 1:res. 1-3.

33 Gazanfer İltar, "Tekke Köyü Hacı Abdullah Halife Camisi Duvar Resimleri," Vakıflar Dergisi 42 (2014), 72.

34 Tolga Uzun, "19. Yüzyıl Osmanlı Duvar Resimlerinde Yeniliğin ve Değişimin Sembolü Tasvirler," XX. Uluslararası Ortaçağ Ve Türk Dönemi Kazıları ve Sanat Tarihi Araştırmaları Sempozyumu Bildirileri (2-6 Kasım 2016), ed. Ela Taş, (Sakarya: Sakarya Üniversitesi Yayınları, 2017), 1:855-856.

35 İnci Kuyulu, “İzmir Bayraklı Yahya Hayati Paşa Köşkü: Kül Olan Resimler,” XVI. Ortaçağ-Türk Dönemi Kazıları ve Sanat Tarihi Araştırmaları Sempozyumu Bildirileri 18-20 Ekim 2012, ed. Meryem Acara Eser, Ebru Bilget Fataha ve Gülseren Koyun (Sivas: Cumhuriyet Üniversitesi Yayınları 2014), res. 7, 10.

36 M. Fatih Müderrisoğlu, "Demirci Ağa Camii," Türk Kültür Varlıkları Envanteri Manisa İlçeleri, ed. Hakkı Acun (Ankara: Türk Tarih Kurumu Yayınları 2013), 10. 
$(1875)^{37}$, Koçarlı Cincin Köyü Cihanoğlu Camii (XVIII. yüzy1l) ${ }^{38}$ doğu duvarında ve bölgedeki pek çok yapıda benzer şekilli buharlı ve yelkenli gemi tasvirlerine rastlamak mümkündür. Küpeler Köyü Camii'nde bulunan tasvir kısmen Cihanoğlu Camii'ndeki gemiye benzemekle birlikte daha naif ve basittir.

Harim kuzey duvarındaki dikkat çeken süslemelerden bir diğeriyse cephenin doğusunda alt bölümde yer alan bir teber ${ }^{39}$ ve yanına asılı keşkül ${ }^{40}$ tasviridir (G. 9). Tekke ikonografisi bakımından oldukça anlam taşıyan bu süslemeler ne yazık ki kısmen tahrip olmuş durumdadır. Özellikle İç Ege ve Teke bölgesi ile Amasya ve Tokat civarındaki pek çok yapıda keşkül ve teberin kullanıldığı benzer tasvirler karşımıza çıkmaktadır. Tokat Zile Yeşilce Köyü Şeyh Eylük Türbesi (XIV. yüzyı1) ${ }^{41}$, Denizli Baklan Boğaziçi Kasabası Eski Cami (1774-75) ${ }^{42}$, Amasya Merzifon Kara Mustafa Paşa Camii şadırvanı (1875) ${ }^{43}$, Aydın Kuyucak Kayran Köyü Camii (XIX. yüzyıl) ${ }^{44}$, Denizli Akköy Belenardıç Torapan Köyü Camisi (1884) ${ }^{45}$ ve Amasya Gümüşhacıköy’de Ali Pir Civan (XX. yüzyıl başları) ile Hacı Nazır Türbeleri (XVI. yüzyıl başları) ${ }^{46}$ keşkül ve teber motiflerine yer verilen örnekler arasındadır.

Aynı cephede, buharlı gemi motifinin hemen altında Adem ile yedim dana Nuh ile girdim tufana üç kere geldim cihana bir daha gelsem gerekdir yazan ilgi çekici bir dörtlüğe yer verilmiştir (G. 10). Bu dörtlük, Türk ve İran edebiyatının yanı sıra özellikle Bektaşi, tekke ve halk edebiyatında karşılaşılan ve devriyye olarak adlandırılan bir manzumedir. Devriyyeler tasavvufta insanın bu dünyaya gelişi, seyri ve yine öteye dönüşünden bahsetmektedir. ${ }^{47}$ Yakın bölgedeki farklı tarikat şeyhlerinin de bu tarz manzumeleri olduğu bilinmektedir. ${ }^{48}$

37 Baha Tanman, "Merzifon Kara Mustafa Paşa Camii Kubbesinde Zileli Emin'in Yarattığı "Osmanlı Dünyası" ve Bu Dünyaya Yansıyan Kişiliği," Sanat Tarihinde İkonografik Araştırmalar, Güner İnal'a Armağan (Ankara: Hacettepe Üniversitesi Yayınları 1993), 498-499.

38 Yurtsal, "Aydın ve Denizli Camilerinde Duvar Resimleri,” 245.

39 Tek veya çift ağızlı bir çeşit balta olan teberler, gezici dervişlere ait bir semboldür. Uzun seyahatlere çıkan dervişlerin koruma silahı olarak kullandıkları bu nesne, daha sonra sembolik bir ifade kazanmıştır. Ekrem Işın, Hoş Gör Ya Hû Osmanlı Kültüründe Mistik Semboller Nesneler (İstanbul: Yapı Kredi Yayınları 1999), 77.

40 Genellikle Hindistan cevizinden yapılan ve yoksul çanağı anlamına gelen keşkülün boyna asmak için bir de zinciri bulunmaktadır. Gezici dervişler içlerine yiyecek ya da içecek koymak için bunları daima yanlarında taşımaktadır. Işın, Hoş Gör Ya Hû Osmanlı Kültüründe Mistik Semboller Nesneler, 73.

41 Halit Çal, "Tokat Zile Yeşilce Köyü Şeyh Eylük Türbesi,” Prof. Dr. Yılmaz Önge Armağanı (Konya: Selçuk Üniversitesi Vakfi Yayınları, 1993), 294-295.

42 Çakmak, "Boğaziçi Kasabası Eski Cami (Baklan/Denizli)," 532.

43 Tanman, "Merzifon Kara Mustafa Paşa Camii Kubbesinde Zileli Emin'in Yarattığı "Osmanlı Dünyası" ve Bu Dünyaya Yansıyan Kişiliği,” 498.

44 Erbil Cömertler Aktuğ-Kadir Pektaş, “Geç Dönem Kalem İşi Süslemeli Bir Eser: Aydın Kuyucak Kayran Köyü Camii,” Medeniyet Sanat, IMÜ Sanat, Tasarım ve Mimarlık Fakültesi Dergisi, 2, (2016), 2: 14.

45 Şakir Çakmak, "Belenardıç (Torapan ) Köyü Camii (Güney/Denizli)," Sanat Tarihi Dergisi VII (1994) 23.

46 Savaş Yıldırım, “Amasya Gümüşhacıköy Türbelerindeki Kalem İşi Süslemeler,” Art Sanat 10 (Temmuz 2018), 314, 327, erişim 11 Mayıs 2019, https://doi.org/10.26650/artsanat.2018.10.0013.

47 Ayrıntılı bilgi için Mustafa Uzun, "Devriyye," Türkiye Diyanet Vakfi İslam Ansiklopedisi, c. 9 (İstanbul: Türkiye Diyanet Vakfı Yayınları, 1994), 251-253.

48 Gürol Pehlivan, “Turgutlu Uşşakî Şeyhi Arif Eren'de Devir Anlayışı,” Uluslararası Turgutlu Sempozyumu Bildirileri, ed. Muzaffer Tepekaya vd. (Turgutlu: Turgutlu Belediyesi Kültür Yayınları, 2018) 1: 103-111. 
Harim kuzey duvarındaki kitabelerde yapının inşa ustası ve hat sanatçısının isimleri ayrı levhalarda açıkça verilmiştir. Süslemeleri yapan ustanın ismi ise devriyye olarak adlandırdığımız dörtlüğün hemen yanında karşımıza çıkmaktadır. Kısmen silindiğinden okuması hayli güç olan bu bölümün okunabilen kısımlarında El-müzehhib Demircili Sofiler Mahallesi'nden Mehmed yazmaktadır (G. 10). Kitabeden yapıdaki duvar resimlerinin Mehmet adlı bir usta tarafından yapıldığı anlaşılmaktadır.

İstanbul'da başlayan duvar resmi geleneği, zamanla İmparatorluğunun dört bir yanında benimsenmiştir. Başlangıçta Anadolu'ya ayanlar tarafından başkentten getirilen sanatçıların, bu yeni gelişen resim türünü yerli ustalara tanıtmış oldukları düşünülmektedir. ${ }^{49}$ Daha sonra bu bezeme anlayışı usta çırak ilişkisiyle gelişmiş ve Anadolu'daki pek çok yapı halk ressamı olarak adlandırılan ustalar tarafından bezenmiştir. Bu ustaların pek çoğu icra ettikleri sanat eserlerine imza atmaktan imtina ettiklerinden, genellikle isimleri bilinmemektedir.

Amasya, Merzifon ve Tokat çevresinde çok sayıda eser veren ve imzasını da atan Zileli Emin $^{50}$ ile Miralayzade Ali Bey ${ }^{51}$ ve Şeyhzade Abdurrahman Efendi ${ }^{52}$ halk ressamlarının en bilinenleri arasındadır. Bunun yanında yakın dönemdeki araştırmalarda Anadolu'nun çeşitli bölgelerinde Darendeli eş-Şeyh Hamza ${ }^{53}$, Nakkaş İbrahim ${ }^{54}$, Bekir ve Şemsi ${ }^{55}$ adlı usta isimlerine de rastlanmaktadır.

Küpeler Köyü Camii duvar resimlerini yapan ustanın Demirci'nin Sofiler (Sofular) Mahallesi'nden olduğu ayrıca belirtilmiştir. Demirci'de XIX. yüzyılda Mevlevi, Rufai ve Nakşibendilere ait tarikatların varlığı bilinmektedir. ${ }^{56}$ Sofular Mahallesi'nde ise yine o yıllarda Kadirî tarikatının Eşrefiye koluna ait bir Tekke mevcuttur. ${ }^{57}$ Yapıda işlenen tekkelerle ilgili semboller ve yazılar dikkate alındığında süslemeleri yapan gezici halk ressamı Müzehhib Mehmed'in, bölgede faaliyet gösteren bu tekkeyle bir bağlantısının olabileceği akla gelmektedir.

49 Renda, Batılllaşma Dönemi Türk Resim Sanatı 1750-1850, 192; Hatipoğlu, "XIX. yüzyıl Osmanlı Camilerinde Kalem işi Tezyinatı," 173-174.

50 Rüçhan Arı, “Anadolu'da Bir Halk Ressamı: Zileli Emin,” Türkiyemiz 16 (1975), 8-13; Tanman, “Merzifon Kara Mustafa Paşa Camii Kubbesinde Zileli Emin'in Yarattığı “Osmanlı Dünyası” ve Bu Dünyaya Yansıyan Kişiliğ̈i," 491-522.

51 Arık, Batılllaşma Dönemi Anadolu Tasvir Sanatı, 97-98.

52 Bozer, "Kula-Emre Köyünde Resimli Bir Cami," 22.

53 Gazanfer İltar, "Tekke Köyü Hacı Abdullah Halife Camisi Duvar Resimleri," 75.

54 Murat Çerkez, "Merzifon Türbeleri,” Atatürk Üniversitesi Güzel Sanatlar Fakültesi Sanat Dergisi 11 (2010), 68.

55 Yasemin Ecesoy, "Gaziantep Duvar Resimlerinde İki Halk Sanatçısı: Bekir ve Şemsi," Mediterranean Journal of Humanities IV/1(2014)159-169, erişim 17 Mayıs 2019. https://doi.org/10.13114/MJH.201416430

56 Gökmen, Tanzimat 'tan II. Meşrutiyet'e Demirci Kazası, 314.

57 Ertan Gökmen, "Demirci Kazasındaki Kadirî Tarikatının Eşrefiye Koluna Ait Tekkenin Vakfiyesi," Vakıflar Dergisi XXIX (2005), 77-87. 


\section{Sonuç}

İncelemiş olduğumuz Demirci Küpeler Köyü Camii, zengin kalemişi ve hat süslemeleri ile dikkati çekmektedir. Yapının son cemaat yeri ve harim duvarlarında dini içerikli hat levhaların yanı sıra natürel ve stilize edilmiş bitkisel süslemeler ile sembolik motiflere yer verilmiştir. Yapı yazı ve süsleme anlayışı bakımından özellikle İç Ege ve Akdeniz bölgesinde yer alan çok sayıda cami ile benzerlikler göstermektedir. Ancak süslemeler, diğer camilere oranla daha basit ve naiftir. Caminin kitabelerinde hem yapı ustasının hem müzehhibin hem de hat sanatçısının isimlerinin verilmiş olması dikkat çekici bir başka unsurdur. İç Batı Anadolu’nun küçük bir dağ köyündeki mütevazı bir camiyi bile böylesi yoğun süsleme ve hatlarla bezeyen ve bölgede faaliyet gösteren tekkelerle bağlantılı olduklarını düşündüğümüz bu ustalara dair ayrıntılı bilgilere henüz sahip değiliz. Fakat bu konuda yapılacak yeni çalışmalar ve saha araştırmaları yepyeni ve ilgi çekici verilere ulaşmamızı sağlayacaktır.

Hakem Değerlendirmesi: Dış bağımsız.

Çıkar Çatışması: Yazar çıkar çatışması bildirmemiştir.

Finansal Destek: Yazar bu çalışma için finansal destek almadığını beyan etmiştir.

Peer-review: Externally peer-reviewed.

Conflict of Interest: The author has no conflict of interest to declare.

Grant Support: The author declared that this study has received no financial support.

\section{Kaynakça/References}

Adamaz, Kadir. “XVI. yüzyılda Demirci Kazası.” Doktora tezi, Celal Bayar Üniversitesi, 2012.

Aktuğ, Erbil Cömertler ve Kadir Pektaş. "Geç Dönem Kalem İşi Süslemeli Bir Eser: Aydın Kuyucak Kayran Köyü Camii. ” Medeniyet Sanat, IMÜ Sanat, Tasarım ve Mimarlık Fakültesi Dergisi 2 (2016): 9-25.

Algaç, Şeyda. “Afyonkarahisar Dazkırı-İdris Köyü Camii ve Kalemişi Bezemeleri.” Van Yüzüncü Yll Üniversitesi Sosyal Bilimler Enstitüsü Dergisi 2, (2017): 421-432.

Arık, Rüçhan. Batılılaşma Dönemi Türk Mimarisi Örneklerinden Anadolu'da Üç Ahşap Cami. Ankara: A.Ü. DTCF Yayınları, 1973.

Arık, Rüçhan. “Anadolu’da Bir Halk Ressamı: Zileli Emin.” Türkiyemiz 16 (1975): 8-13.

Arık, Rüçhan. Batılılaşma Dönemi Anadolu Tasvir Sanatı. Ankara: Türkiye İş Bankası Kültür Yayınları, 1976.

Başaranbilek, Emin. Lübbey Kışlağı ve Lübbey Camisi. İstanbul: Mas Matbaacılık, 2015.

Bozer, Rüstem. “Kula-Emre Köyünde Resimli Bir Cami.” Türkiyemiz 53 (1987): 15-22.

Çakmak, Şakir. "Belenardıç (Torapan) Köyü Camii (Güney/Denizli).” Sanat Tarihi Dergisi VII (1994): 19-26.

Çakmak, Şakir. "Boğaziçi Kasabası Eski Cami Baklan/Denizli.” 9. Milletlerarası Türk Sanatları Kongresi (23-27 Eylül 1991). Ankara: Kültür Bakanlığı Yayınları, 1995.

Çakmak, Şakir. "Foça'daki Türk Eserleri.” Geçmişten Günümüze Foça Uluslararası Sempozyumu. İzmir: Foça Belediyesi Yayınları, 1996. 
Çakmak, Şakir. Muğla Cami ve Mescitleri. Muğla: Muğla Belediyesi Kültür Yayınları, 2013.

Çal, Halit. "Tokat Zile Yeşilce Köyü Şeyh Eylük Türbesi.” Prof. Dr. Yılmaz Önge Armağanı. Konya: Selçuk Üniversitesi Vakfi Yayınları, 1993.

Çerkez, Murat. “Merzifon Türbeleri.” Atatürk Üniversitesi Güzel Sanatlar Fakültesi Sanat Dergisi 11 (2010): 65-82.

Ecesoy, Yasemin. “Gaziantep Duvar Resimlerinde İki Halk Sanatçısı: Bekir ve Şemsi.” Mediterranean Journal of Humanities, IV/1 (2014):159-169, Erişim 17 Mayıs 2019. https://doi.org/10.13114/ MJH.201416430

Emecen, Feridun. "Saruhanoğullar1.” Türkiye Diyanet Vakfi İslam Ansiklopedisi. 36, İstanbul: Türkiye Diyanet Vakfi Yayınları, 2009, 170-171.

Eryılmaz, Halil İbrahim. "Yuntdağı Yenice Mahallesi Camii Yazıları.” Manisa Celal Bayar Üniversitesi Sosyal Bilimler Dergisi Sosyal Bilimler Dergisi 16/3, (2018): 545-580.

Gökmen, Ertan. "Hurûfât Defterlerine Göre Demirci Kazası ve Köylerinde Cami ve Mescitler (1690-1830).” Celal Bayar Üniversitesi Sosyal Bilimler Dergisi 3/2 (2005): 21-56.

Gökmen, Ertan. "Demirci Kazasındaki Kadirî Tarikatının Eşrefiye Koluna Ait Tekkenin Vakfiyesi." Vakuflar Dergisi XXIX (2005): 77-87.

Gökmen, Ertan. Tanzimat'tan II. Meşrutiyet'e Demirci Kazası. İzmir: Demirci Belediyesi Kültür Yayınları, 2007.

Gülgen, Hicabi. “Bursa Keles İlçesi Dedeler Köyü Camii ve Süslemeleri.” Uludağ Üniversitesi İlahiyat Fakültesi Dergisi 21/1 (2012): 63-86.

Gültekin, R. Eser. "Türklerde Bereket Sembolü Olarak Kullanılan Meyve Motifleri ve Bunların Mimaride Değerlendirilmesi.” Turkish Studies 3/5 (2008): 9-31, Erişim 11 Mayıs 2019. http:// dx.doi.org/10.7827/TurkishStudies.408

Gürbıyı, Cengiz. Karaburun Yarımadası'nda Türk Mimarisi. İstanbul: Arkeoloji ve Sanat Yayınları, 2009.

Gürsoy, Elif. "Uşak İli Sivaslı ilçesi Akarca Köyü Camisi.” Elektronik Sosyal Bilimler Dergisi 62 (Temmuz 2017): 1001-1014. Erişim 8 Mayıs 2019. https://doi.org/10.17755/esosder.329109.

Işın, Ekrem. Hoş Gör Ya Hû Osmanlı Kültüründe Mistik Semboller Nesneler. İstanbul: Yapı Kredi Yayınları, 1999.

İltar, Gazanfer. "Tekke Köyü Hacı Abdullah Halife Camisi Duvar Resimleri." Vakıflar Dergisi 42 (2014): 69-80.

Kuyulu, İnci. "Geç Dönem Anadolu Tasvir Sanatından Yeni Bir Örnek: Soma Damgacı Camii." Arkeoloji-Sanat Tarihi Dergisi IV (1988): 67-78.

Kuyulu, İnci. “Kırkağaç Çiftehanlar Camii.” Arkeoloji-Sanat Tarihi Dergisi V (1990): 103-115.

Kuyulu, İnci. “Bademli Kılcızade Mehmet Ağa Camii.” Vakıflar Dergisi 24 (1994): 146- 158.

Kuyulu, İnci. "İzmir Bayraklı Yahya Hayati Paşa Köşkü: Kül Olan Resimler.” XVI. Ortaçağ-Türk Dönemi Kazıları ve Sanat Tarihi Araştırmaları Sempozyumu Bildirileri 18-20 Ekim 2012. Ed. Meryem Acara Eser, Ebru Bilget Fataha ve Gülseren Koyun, Sivas: Cumhuriyet Üniversitesi Yayınlar1 2014, 529-545.

Müderrisoğlu, M. Fatih. "Köpüler Köyü Eski Camii.” Türk Kültür Varlıkları Envanteri Manisa İçeleri. Ed. Hakkı Acun, Ankara: Türk Tarih Kurumu Yayınları, 2013, 37-46. 
Müderrisoğlu, M. Fatih. “Demirci Ağa Camii.” Türk Kültür Varlıkları Envanteri Manisa İlçeleri. Ed. Hakkı Acun, Ankara: Türk Tarih Kurumu Yayınları, 2013, 3-11.

Pehlivan, Gürol. “Turgutlu Uşşakî Şeyhi Arif Eren'de Devir Anlayışı.” Uluslararası Turgutlu Sempоzyити Bildirileri. Ed. Muzaffer Tepekaya vd., Turgutlu: Turgutlu Belediyesi Kültür Yayınları, 2018,103-111.

Pektaş, Kadir ve Hediye Gelen Altındirek. “Çivril Bulgurlar Köyü Camii Üzerine.” Eumeneia Şeyhlü-Işıklı. Ed. Bilal Söğüt, İstanbul: Ege Yayınları, 2011.

Renda, Günsel. Batılılaşma Döneminde Türk Resim Sanatı: 1700-1850. Ankara: Hacettepe Üniversitesi Yayınları, 1977.

Tali, Şerife. "Kırşehir/Mucur'daki Hüseyin Ağa Camii ile Emine Hanım Camii’nin Kalemişleri.” Uluslararası Sosyal Araştırmalar Dergisi Prof. Dr. Hamza Gündoğdu Armağanı 6/25 (2013): 504-528.

Tanman, M. Baha. "Merzifon Kara Mustafa Paşa Camii Şadırvanının Kubbesinde Zileli Emin'in Yarattığ1 “Osmanlı Dünyası” ve Bu Dünyaya Yansıyan Kişiliği.” Sanat Tarihinde İkonografik Araştırmalar Güner İnal’a Armağan. Ankara: Hacettepe Üniversitesi Yayınları, 1993, 491-523.

Tekinalp, Pelin Şahin. "Batılılaşma Dönemi Duvar Resmi.” Türkler Ansiklopedisi. 15, Ankara: Yeni Türkiye Yayınları, 2002, 440-448.

Uzun, Mustafa. "Devriyye.” Türkiye Diyanet Vakfi İslam Ansiklopedisi. 9, İstanbul: Türkiye Diyanet Vakfi Yayınları, 1994, 251-253.

Uzun, Tolga. “19. Yüzyıl Osmanlı Duvar Resimlerinde Yeniliğin ve Değişimin Sembolü Tasvirler.” XX. Uluslararası Ortaçă̆ Ve Türk Dönemi Kazıları ve Sanat Tarihi Araştırmaları Sempozyumu Bildirileri (2-6 Kasım 2016). 2. cilt, Ed: Ela Taş, Sakarya: Sakarya Üniversitesi Yayınları, 2017, 852-862.

Y1ldırım, Savaş. “Amasya Gümüşhacıköy Türbelerindeki Kalem İşi Süslemeler.” Art Sanat 10 (Temmuz 2018): 293-327, Erişim 11 Mayıs 2019. https://doi.org/10.26650/artsanat.2018.10.0013

Yurtsal, Tuğçe. “Aydın ve Denizli Camilerinde Duvar Resimleri. ”Yüksek Lisans Tezi, Gazi Üniversitesi, 2009. 
